\title{
Kenya: Ex Post Assessment of Longer-Term Program Engagement
}

This Ex Post Assessment of Longer-Term Program Engagement paper for Kenya was prepared by a staff team of the International Monetary Fund as background documentation for the periodic consultation with the member country. It is based on the information available at the time it was completed on August 4, 2008. The views expressed in this document are those of the staff team and do not necessarily reflect the views of the government of Kenya or the Executive Board of the IMF.

The policy of publication of staff reports and other documents by the IMF allows for the deletion of market-sensitive information.

Copies of this report are available to the public from

International Monetary Fund • Publication Services

700 19th Street, N.W. • Washington, D.C. 20431

Telephone: (202) 623-7430 • Telefax: (202) 623-7201

E-mail: publications@imf.org • Internet: http://www.imf.org

Price: $\$ 18.00$ a copy

\section{International Monetary Fund \\ Washington, D.C.}





\title{
INTERNATIONAL MONETARY FUND
}

\section{KENYA}

\section{Ex Post Assessment of Longer-Term Program Engagement}

\author{
Prepared by a staff team from African, Fiscal Affairs, and \\ Policy Development and Review Departments ${ }^{1}$
}

Authorized for distribution by the African and

Policy Development and Review Departments

August 4, 2008

Contents $\quad$ Page

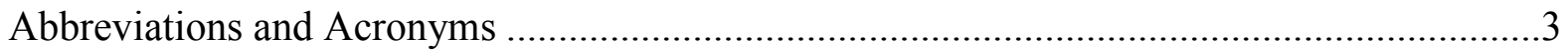

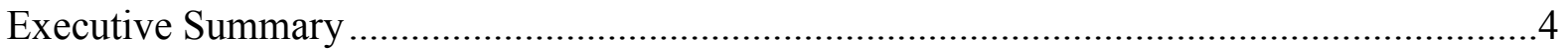

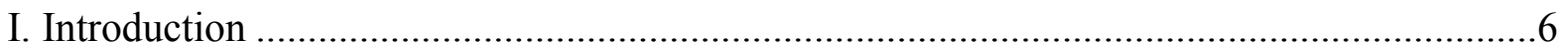

II. Economic Performance During the EPA Period ....................................................

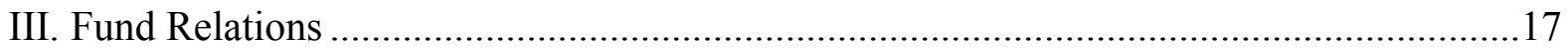

IV. Key Issues in Fund Engagement.....................................................................22

A. Policy Advice and Program Design in Core Macroeconomic Areas .....................23

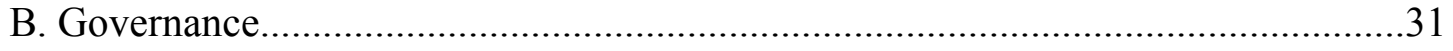

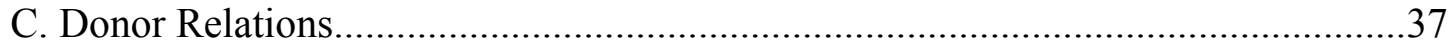

V. Lessons Learned and Policy Challenges Going Forward ..........................................40

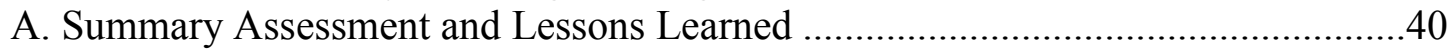

B. Policy Challenges Going Forward ................................................................. 42

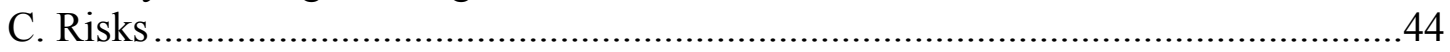

D. Framework for Future Fund Engagement with Kenya ......................................44

Table

1. Fund Arrangements with Kenya, 1993-2007 ..................................................18

\footnotetext{
${ }^{1}$ Prepared by a team comprising Mark Horton (FAD, head), Peter Dohlman (PDR), Greetje Everaert (FAD), and Iyabo Masha (AFR), with research assistance by Juan Yepez (FAD) and additional support from Olessia Korbut (AFR), Emmanuel Hife (PDR), and Mercy Anbiah (FAD).
} 


\section{Figures}

1. Summary Program Performance, 1993/94-2005/06 ...............................................10

2. Relations with the Donor Community, 1990-2006 …............................................11

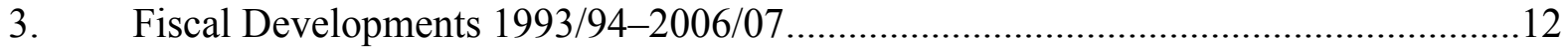

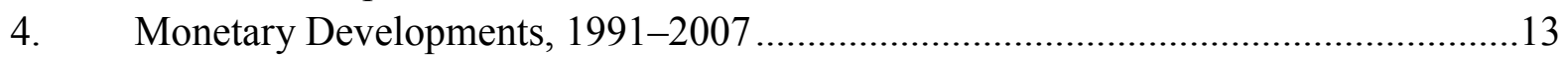

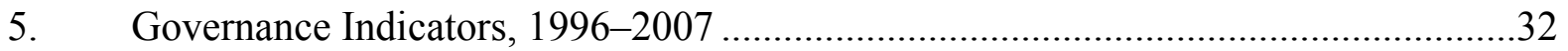

6. Program vs. Outturn Program Support, 1993/94-2006/07 .....................................38

\section{Boxes}

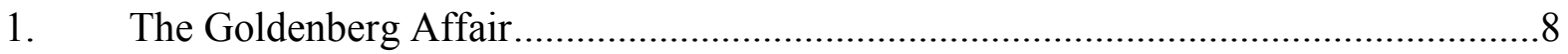

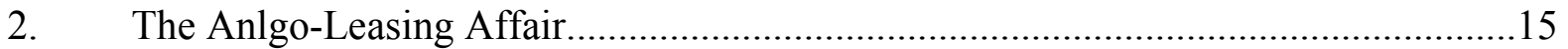

3. Actions to Bring the 1996 ESAF Back On-Track .......................................................34

4. Structural Conditionality Outside of the Governance Area .......................................36

Appendices

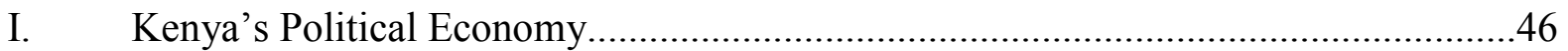

II. Kenya's Relations with the World Bank ..................................................................48

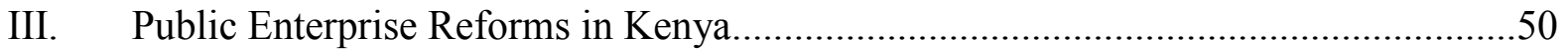

IV. Rationalization of Civil Service Employment .......................................................52

V. The Ambitious Agenda of the Dream Team .............................................................54

VI. The On-and-Off Nature of Donor Support in Kenya ...............................................56

Annex

I. The Views of the Kenyan Authorities and Other Stakeholders 


\section{Abbreviations AND ACRONYMS}

\begin{tabular}{|c|c|}
\hline AG & Attorney General \\
\hline C\&AG & Comptroller and Auditor General \\
\hline CBK & Central Bank of Kenya \\
\hline CG & Consultative Group \\
\hline $\mathrm{CSO}$ & Civil society organization \\
\hline DSA & Debt Sustainability Analysis \\
\hline EAC & East Africa Community \\
\hline EGG & Economic Governance Group (of donors in Kenya) \\
\hline EPA & Ex Post Assessment (of Longer-Term Program Engagement) \\
\hline ESAF & Enhanced Structural Adjustment Facility \\
\hline FSAP & Financial Sector Assessment Program \\
\hline FSSA & Financial Sector Stability Assessment \\
\hline GAP & Governance Action Plan (Kenya) \\
\hline HIPC & Heavily Indebted Poor Countries (debt relief initiative) \\
\hline ICM & Informal Country Matters (Executive Board sessions) \\
\hline IPO & Initial Public Offering \\
\hline KACA & Kenya Anti-corruption Authority \\
\hline $\mathrm{KACC}$ & Kenya Anti-corruption Commission \\
\hline KANU & Kenya African National Union \\
\hline $\mathrm{KCB}$ & Kenya Commercial Bank \\
\hline KPLC & Kenya Power \& Lighting Company \\
\hline КРTC & Kenya Post \& Telecommunication Corporation \\
\hline $\mathrm{KR}$ & Kenya Railways \\
\hline KRA & Kenya Revenue Authority \\
\hline LEG & Legal Department \\
\hline MDRI & Multilateral Debt Relief Initiative \\
\hline MEFP & Memorandum of Economic and Financial Policies \\
\hline MOF & Ministry of Finance \\
\hline NBK & National Bank of Kenya \\
\hline NCPB & National Cereals and Produce Board \\
\hline NDA & Net Domestic Assets \\
\hline NDF & Net Domestic Financing \\
\hline NPL & Non-performing Loan \\
\hline NSSF & National Social Security Fund \\
\hline OGE & Office of Governance and Ethics \\
\hline PEs & Public Enterprises \\
\hline PFM & Public Financial Management \\
\hline PIN & Public Information Notice \\
\hline PRGF & Poverty Reduction and Growth Facility \\
\hline PS & Permanent Secretary \\
\hline PSI & Policy Support Instrument \\
\hline REER & Real Effective Exchange Rate \\
\hline SME & Small and Medium Enterprises \\
\hline SMP & Staff-Monitored Program \\
\hline TA & Technical Assistance \\
\hline
\end{tabular}




\section{EXECUTIVE SUMMARY}

This Ex Post Assessment (EPA) focuses on 1993-2007, when Kenya was engaged in four successive Fund arrangements. Two aspects of the engagement were noteworthy: a strong focus on governance - dating from a 1993 corruption scandal — and difficulties in completing program reviews, in spite of relatively prudent policies and gradual progress on reforms. Kenya's performance and relations with the Fund were viewed as disappointing until a recent pick-up of growth and improved implementation of structural reforms.

\section{Macroeconomic policy design was broadly appropriate and implementation was generally sound. Growth slowed in the 1990s, but picked up after the 2002 elections, reflecting buoyant global conditions, structural reforms, and a surge of private capital inflows. Monetary policies were complicated by a reluctance to allow for full interest and exchange rate flexibility. Fiscal policy advice and implementation were sound, although an earlier focus on domestic debt consolidation would have been desirable. Progress was made in structural reform, albeit often slower than programmed and with setbacks that raised doubts about ownership. Reforms focused on governance, civil service employment, parastatal operations, revenue administration, public financial management (PFM), and financial sector supervision and development. Extensive Fund technical assistance (TA) was moderately effective.}

The attention given to governance was warranted, given the size and nature of two major scandals; however, the approach became overly reactive, and programs became overloaded. A long focus on strengthening independent prosecution authority put the Fund in a difficult position of enforcing accountability, and at times specific measures had tenuous links with macro- and program-criticality. With improved ownership and performance, World Bank engagement on governance issues, and a change in the Fund's governance approach in Kenya, two program reviews were completed in 2007. However, an earlier strategic regrouping, disengagement, or change in program modalities should have been pursued.

Donors played a strong role in shaping Kenya's engagement with the Fund. Donors repeatedly limited aid, reflecting concerns with governance. This squeezed capital and poverty-reducing spending and constrained domestic debt consolidation, but also was a factor in relatively sound revenue performance, as Kenya adjusted to limited external support. External debt was reduced from 75 percent of GDP in 1993/94 to under 20 percent at present, although Kenya did not qualify or benefit from the Heavily Indebted Poor Countries (HIPC) or Multilateral Debt Relief initiatives (MDRI).

Notwithstanding the disappointing past engagement, the Fund can play a role in helping the authorities design and implement sound policies going forward. The recent postelection violence made clear the need for sustained and equitable private sector-led 
growth and further institutional improvements. Risks to continued Fund engagementnotably, the political situation and governance-will need to be considered. Options for continued cooperation include a low-access arrangement under the Poverty Reduction and Growth Facility (PRGF) or a Policy Support Instrument (PSI), as well as a surveillance-only relationship. Important considerations will be Kenya's interest (or non-interest) in a particular type of engagement or relationship. 


\section{INTRODUCTION}

1. Kenya's performance and its relations with the Fund were disappointing, until a recent pick-up of growth. Performance deteriorated sharply in the early 1990s, and while stability was restored, growth stagnated, as poor governance and limited external financing posed constraints. Policies were relatively prudent after 1993 and adjusted to limited donor support. With creditors reluctant to lend, external debt was reduced from 75 percent of GDP in 1993/94 to under 20 percent at present. ${ }^{2}$ Conditions improved in recent years, with a sharp pick-up of growth, reflecting buoyant global conditions, progress with structural reforms, and a surge of private capital inflows.

2. This EPA focuses on Kenya's relations with the Fund since 1993. During this time, Kenya was continuously engaged in programs, beginning with a Staff-Monitored Program (SMP) in 1993 and followed by four arrangements. ${ }^{3}$ The EPA covers a longer period than usual, as key issues that emerged in 1992-93 remained constant. In particular, a major corruption scandal from that time cast a long shadow over relations. Two aspects of the engagement were noteworthy - a strong focus on governance and difficulties in completing program reviews.

3. The report was discussed with the authorities, donors, and other stakeholders in June, in conjunction with the 2008 Article IV consultations. The authorities found the report to be balanced and objective, and they welcomed the opportunity to assess past engagement. They appreciated that the EPA highlighted Kenya's track record of relatively prudent economic management and improved performance in recent years. At the same time, they considered that conditionality, particularly in the governance area, did not reflect realistic timetables or the constraints of Kenya's legal system or political environment. While recognizing legitimate governance concerns, they felt that the number and nature of conditions (and perceived cross-conditionality) were inconsistent with the treatment of other Fund member countries. This undermined program ownership, along with other factors, including requiring parliamentary passage of legislation and the coincidence of new Fund arrangements with drought and debt rescheduling. This meant that Kenya had been forced by difficult circumstances to agree to unrealistic programs. In addition, senior officials of the Central Bank of Kenya (CBK) did not concur with the report's conclusion that the CBK's independence was overly constrained. Discussions with line ministry officials focused on the links of constrained macroeconomic policies, limited donor support, and repayment of

\footnotetext{
${ }^{2}$ Kenya did not qualify for the HIPC initiative or the MDRI, as it was not found to face an unsustainable external debt burden beyond a level that could be addressed by traditionally available debt relief mechanisms. Kenya's per capita GDP was above the $\$ 380$ threshold at the end of 2004.

${ }^{3}$ Kenya also had a three-year ESAF arrangement during 1989-92. Only one Fund member country has had more arrangements under the Enhanced Structural Adjustment Facility (ESAF) or the PRGF—six — and just one other member has had five such arrangements.
} 
external debt to cuts in social service and investment spending, with negative implications for growth and poverty reduction. Looking forward, the authorities noted the importance of future Fund engagement for signaling to donors and financial markets, as well as a platform for policy advice and technical assistance. They were not specific as to the form or timing of possible future engagement, noting that a cabinet-level committee was assessing the various options, including an arrangement under the PSI. Representatives of civil society organizations (CSOs) and the donor community see a strong case for continued close engagement, given risks and uncertainties and Kenya's outstanding development needs. CSO and donor representatives also urged that governance remain a key focus of Fund engagement. All parties welcomed the opportunity to draw lessons from the past engagement and called for a "partnership" rather than a "supervisory" relationship going forward. A summary of the views of the authorities and other stakeholders is provided in Annex I.

\section{Economic Performance During the EPA Period}

\section{Crisis and stabilization}

4. Macroeconomic performance worsened in 1992, as Kenya was buffeted by drought and power shortages, weak commodity prices, a suspension of new donor aid to the government, and fiscal slippages and ethnic tensions ahead of elections. ${ }^{4}$ External arrears emerged and reached over $\$ 600$ million. The situation was exacerbated by the "Goldenberg affair," a large misappropriation of CBK and budgetary funds (Box 1). Loose monetary policy, in part reflecting Goldenberg payouts, led to speculation against the exchange rate peg. Reserves declined precipitously, and foreign exchange controls were reintroduced (Figure 1).

5. The authorities restored stability by tightening fiscal and monetary policy. Targeting a reduction of the civil service and parastatal spending, the authorities slashed the deficit in 1994/95 and 1995/96. This contributed to a sharp tightening of monetary conditions and a reduction of inflation. Banks involved in Goldenberg were closed, and exchange restrictions were reversed. However, interest rate differentials contributed to capital inflows, which were sterilized, and the accumulation of short-term debt complicated fiscal consolidation going forward. Donors were reengaged, and a nonconcessional Paris Club rescheduling of external arrears took place in January 1994.

\section{Declining growth through the rest of the 1990s and into the 2000s}

6. Difficult conditions persisted during the remainder of the 1990s and into the early 2000s. As elsewhere in sub-Saharan Africa, weak commodity prices, security

\footnotetext{
${ }^{4}$ Appendix I provides a discussion of Kenya's political economy.
} 


\section{Box 1. The Goldenberg Affair}

The Goldenberg scandal involved irregular payments from the Ministry of Finance (MOF) and the CBK during 1990-93 (Goldenberg International was a company that received payments). The case was noteworthy for its size, the range of the channels used, its coincidence with the 1992 elections, and the lack of conclusive legal follow-up.

- Size. Some Ksh 21.6 billion were misappropriated, equivalent to $\$ 600$ million or 6 percent of GDP.

- Channels. At least five different channels were used to acquire funds, including payment of Ksh 15.9 billion by the CBK for foreign exchange purchased but not delivered. Commercial banks involved in the scheme also used overdrafts with the CBK without repayment and a rediscount window under an export pre-shipment financing facility, and did not meet statutory cash ratios. Credit extended through these channels reached 71 percent of reserve money at end-March 1993. Irregular payments were also made by the treasury for fraudulent gold exports under an export promotion scheme.

- Immediate follow-up and high level involvement. The finance minister at the time the scheme operated relinquished the post in February 1993, prior to the scandal coming to light, and continued to serve as Kenya's vice president through 1997 and again in 1999-2002. An investigation by an international accounting firm was conducted by his successor at the MOF, who closed the export compensation and pre-shipment financing schemes. When the scandal broke in mid-1993, the CBK governor resigned, followed by the treasury permanent secretary (PS) in April 1994.

- Subsequent developments. Two-thirds of the missing funds were recovered, and while the authorities conducted several investigations, there were no prosecutions of high-level officials alleged to be involved. Cases against the former CBK governor, treasury PS, and the former managing director of Goldenberg International continue in the courts.

concerns, and recurrent drought contributed to slow growth (see chart below). ${ }^{5}$ However, limited external financing, poor public spending composition, and the impact of weak governance on infrastructure and the business climate meant that Kenya experienced slower growth in the 1990s and a stronger pick-up from 2003.

\footnotetext{
${ }^{5}$ The 1998 U.S. Embassy bombing and terrorist attacks on coastal resorts in 2002 negatively impacted tourism.
} 
Growth and Inflation in Kenya, Neighboring Countries, and

Sub-Saharan Africa Oil Importing Countries, 1990-2006
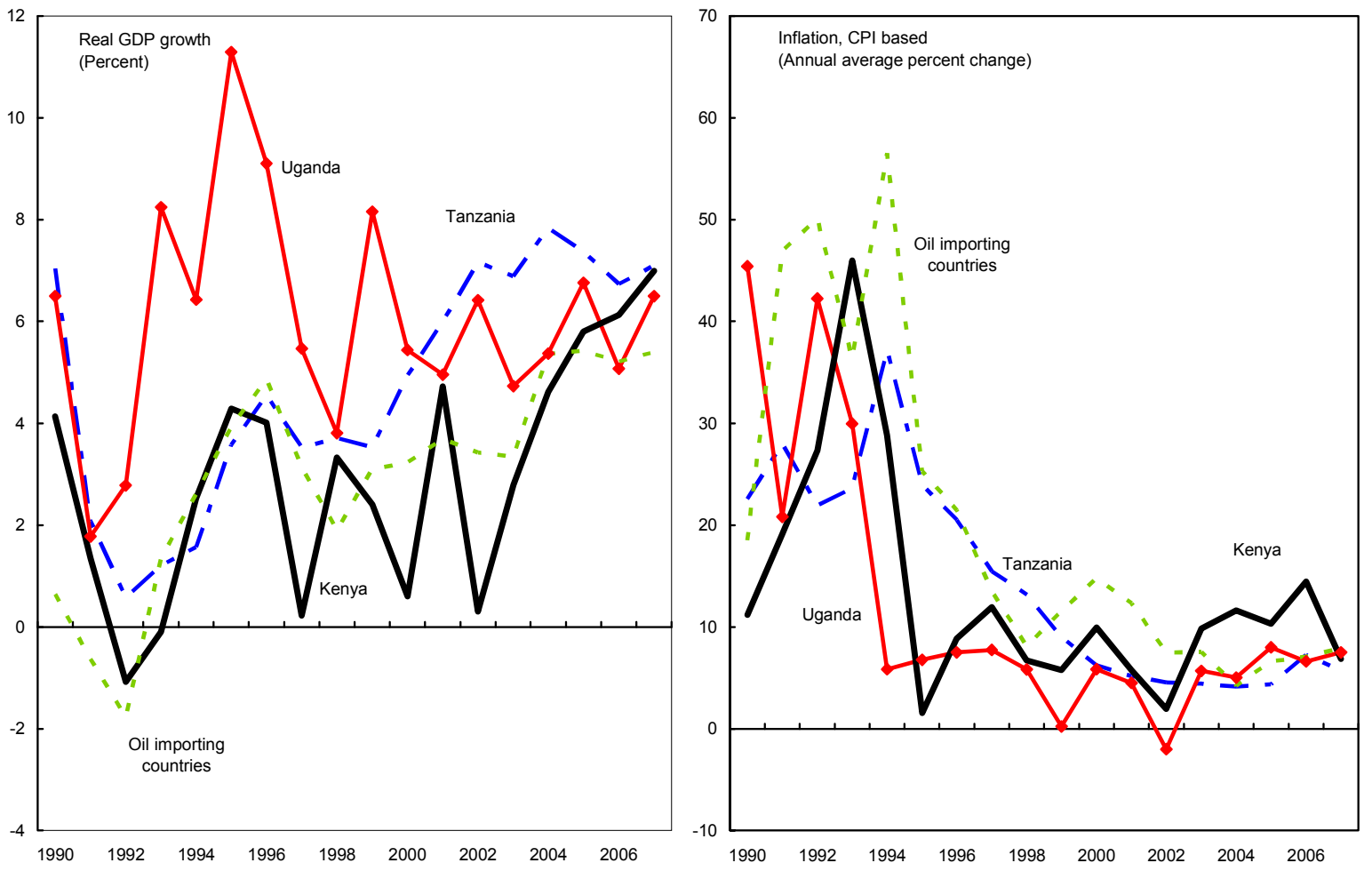

Source: IMF, African Department Regional Economic Outlook (October, 2007). 
Figure 1. Kenya: Summary Program Performance, 1993/94-2005/06 1/
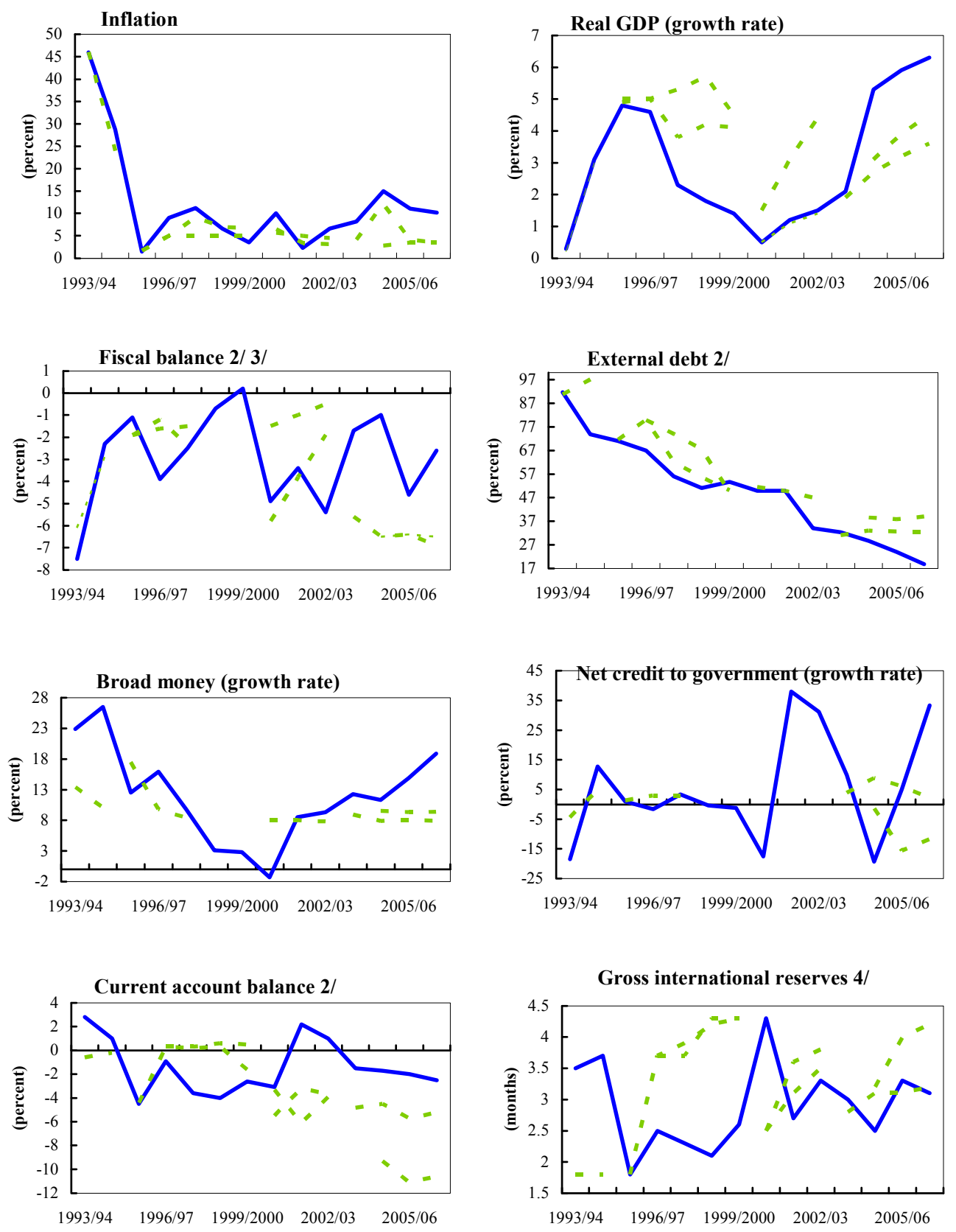

Solid line - actual values.

Dashed line - staff projections.

Source: IMF country documents.

1/ Fiscal year July-June.

2/ In percent of GDP.

3/ Excluding grants, commitment basis.

4/ In months of imports. 
7. Reflecting concerns with governance, donors limited aid throughout the period. These were focused on the disappointing judicial follow-up to Goldenberg and broader perceptions that corruption was rife. Kenya received declining levels of support, far lower than in neighboring countries (Figure 2).

Figure 2. Kenya: Relations with the Donor Community, 1990-2006 1/
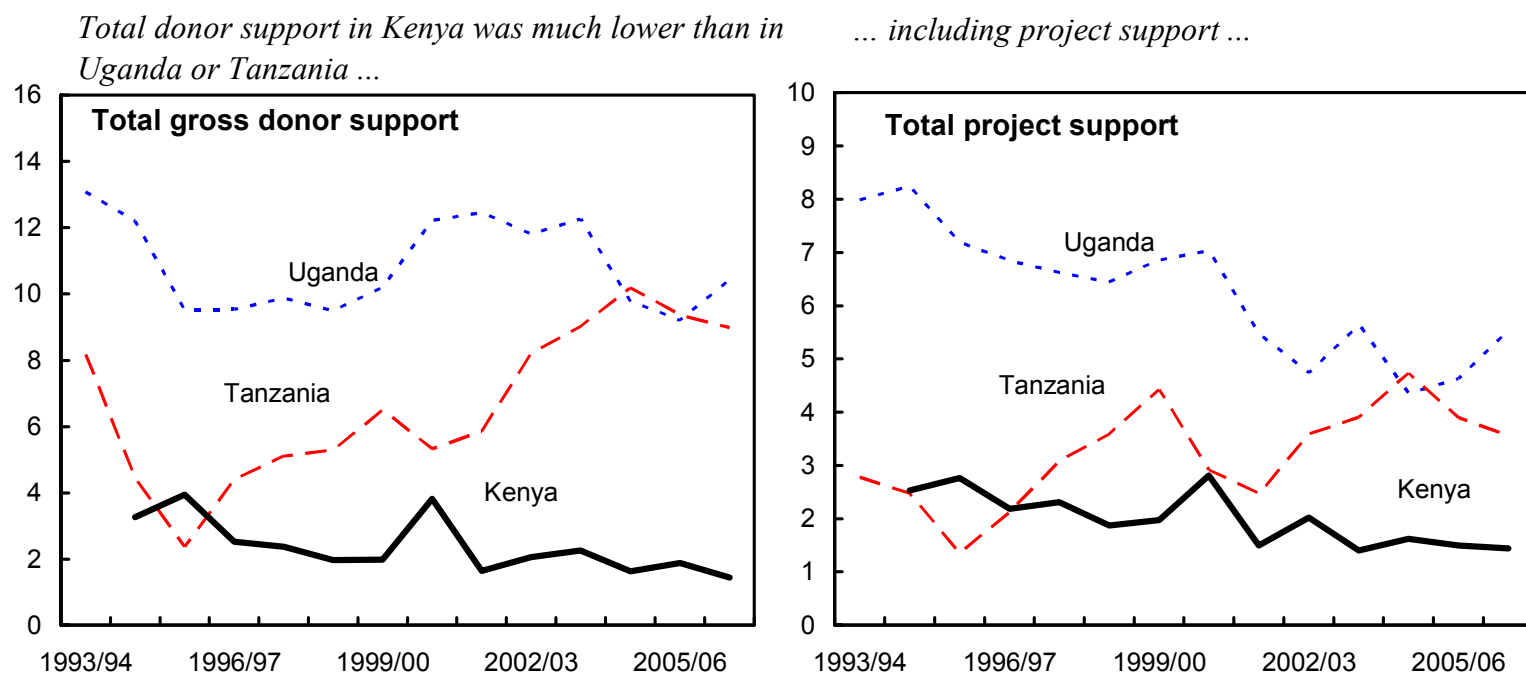

...but especially for program grants and loans.

These differences were also reflected in net foreign

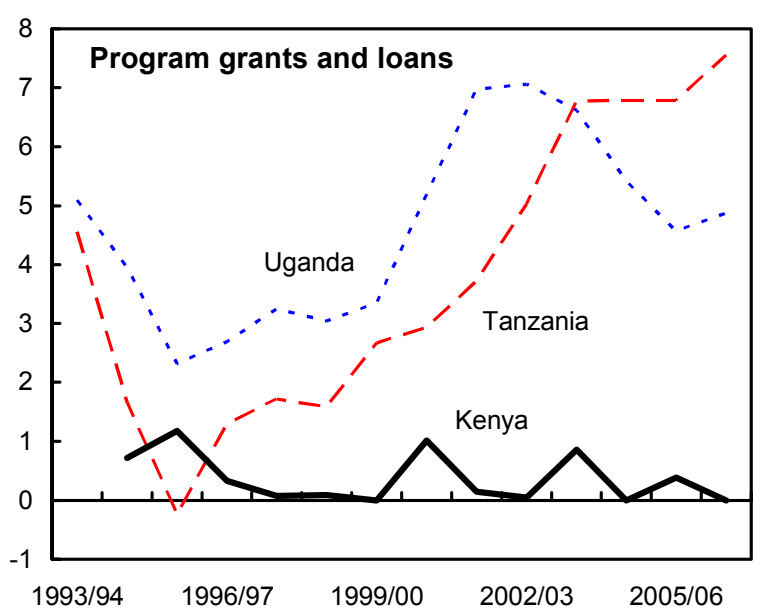

financing flows (fiscal concept).

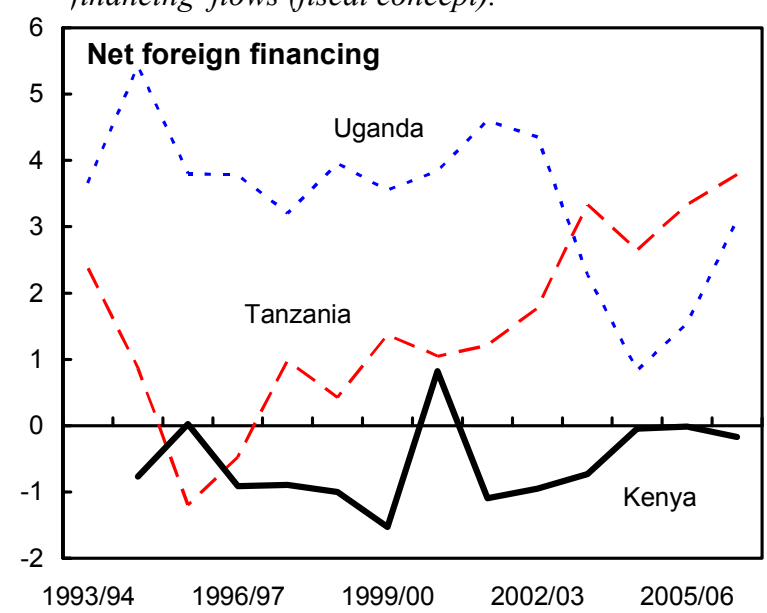

Sources: Country authorities; IMF country documents; OECD DAC database.

$1 /$ In percent of GDP, unless otherwise specified.

8. Lack of external assistance limited domestic debt consolidation. Fiscal policy was relatively prudent, as the overall deficit, including grants averaged 1.6 percent of GDP during 1993/94-2002/03, and the primary surplus averaged 3.3 percent of GDP (Figure 3). 
Figure 3. Kenya: Fiscal Developments 1993/94-2006/07 (In percent of GDP)

Positive primary balances resulted in low overall deficits...

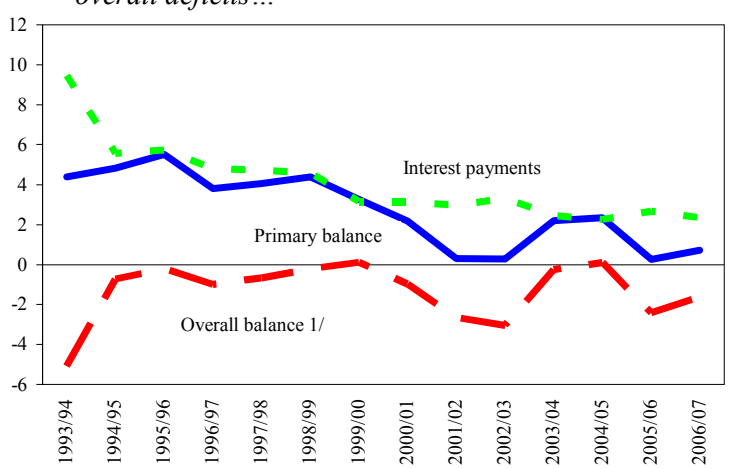

... in part reflecting low donor support.

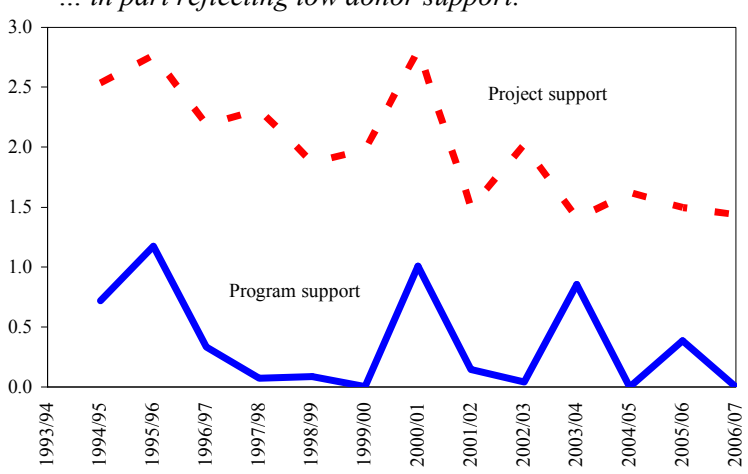

... and limited domestic debt consolidation, although external debt was reduced sharply, without HIPC or

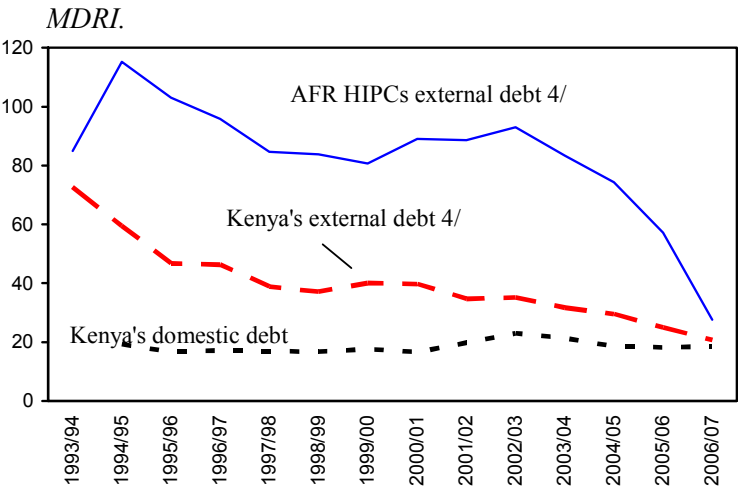

...however, net foreign financing was mostly negative...

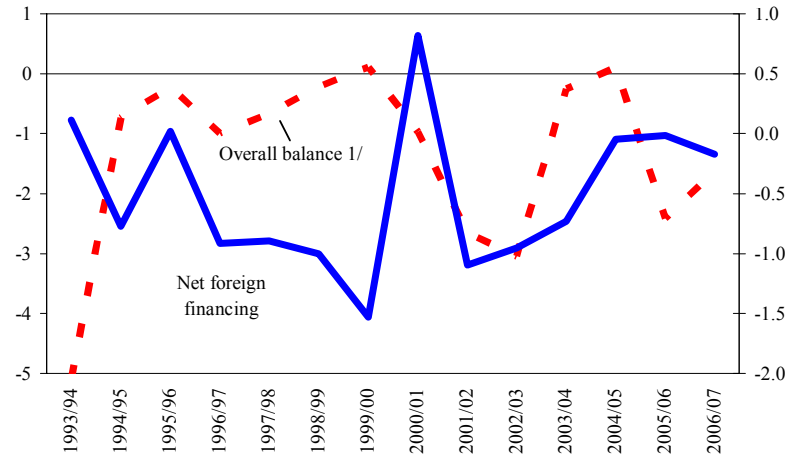

This contributed to substantial domestic borrowing ...

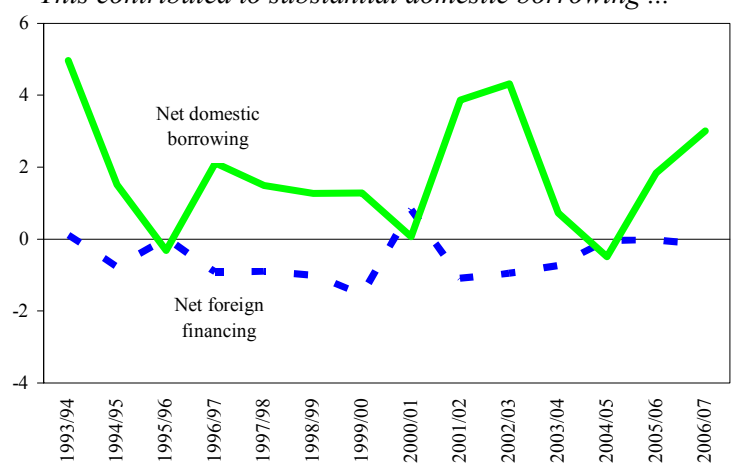

Expenditure composition improved, but fiscal space for higher development outlays remained low.

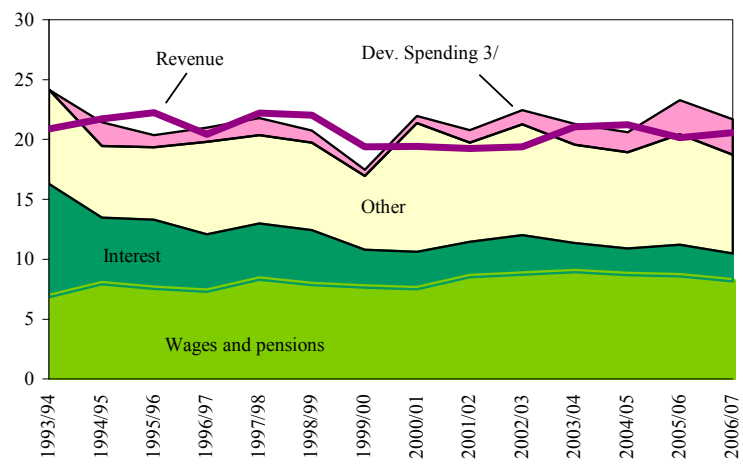

Sources: Kenyan authorities; IMF country documents; IMF, African Department database; and IMF World Economic Outlook.

1/ Cash basis, including grants.

2/ Net, end of period.

3/ Domestically financed.

4/ Calendar year.

However, even small overall deficits contributed to sustained domestic borrowing, as net foreign financing was negative in every year except 2000/01, when a nonconcessional Paris Club rescheduling took place. Net foreign financing to the budget during the 1994/952006/07 period averaged -0.6 percent of GDP annually and amounted to a cumulative 
negative $\$ 1$ billion. ${ }^{6}$ External debt was reduced sharply, but net domestic debt remained at around 20 percent of GDP. Interest payments came down gradually, with a lengthening of maturities and reduction of the risk premium.

\section{9. $\quad$ Limited financing squeezed} $\begin{array}{cc}\text { capital spending, which contributed } & \text { Kenya Revenue Performance, 1993-2007 } \\ \text { (In percent of GDP) }\end{array}$

to a deterioration of

infrastructure, weak growth, and limited poverty reduction. Civil service reforms reduced positions by nearly a quarter from 1993/94 to 2003/04, nonstrategic companies were sold, and cost-cutting improved performance of large parastatals. However, wage increases limited wage bill savings, domestic arrears emerged frequently, and domestically financed capital spending remained very low, at an average of just 1.1 percent of GDP, which included low-quality projects and projects that were not completed. Limited financing did provide an impetus to sustain relatively strong revenue performance

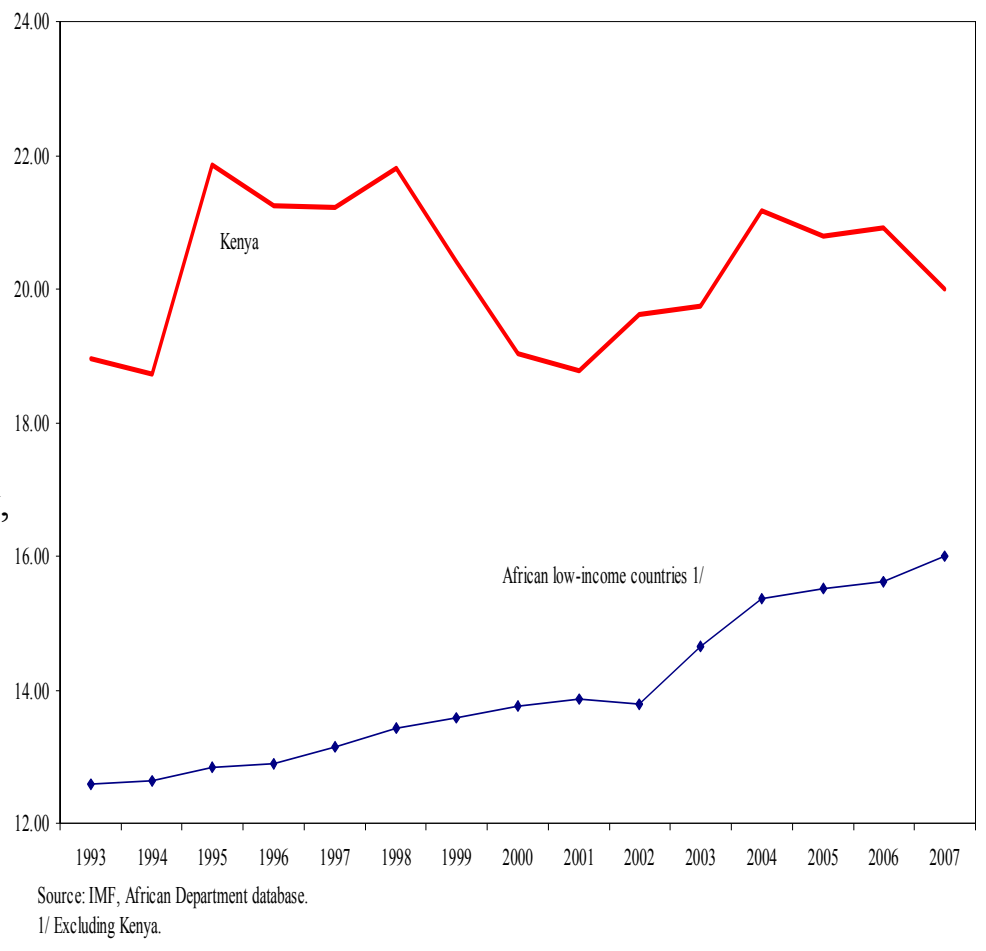
(see chart).

10. Monetary conditions remained relatively tight through 2002, as growth slowed. With weak aggregate demand and strict limits on CBK financing for the government, inflation slowed to below 3 percent (Figure 4). Reform of two major state banks - the National Bank of Kenya (NBK) and Kenya Commercial Bank (KCB) — did not advance, and there were problems with several smaller banks during the period.

\section{Improved performance over the past five years}

\section{A broad coalition government came to power in 2003 on an anti-corruption} platform. Elections in late 2002 ended the 24-year tenure of President Daniel arap Moi and the 40-year rule of the Kenya African National Union (KANU). The new government

\footnotetext{
${ }^{6}$ Total net inflows to the budget — including project and program grants — amounted to \$1 billion; foreign interest payments were $\$ 1.5$ billion. On a broader basis, all inflows to Kenya from donors (OECD ODA data) amounted to $\$ 8.3$ billion ( $\$ 224$ per capita, based on current population estimates), compared with $\$ 16.9$ billion for Tanzania ( $\$ 429$ per capita) and $\$ 12.1$ billion to Uganda (\$400 per capita).
} 
Figure 4. Kenya: Monetary Developments, 1991-2007
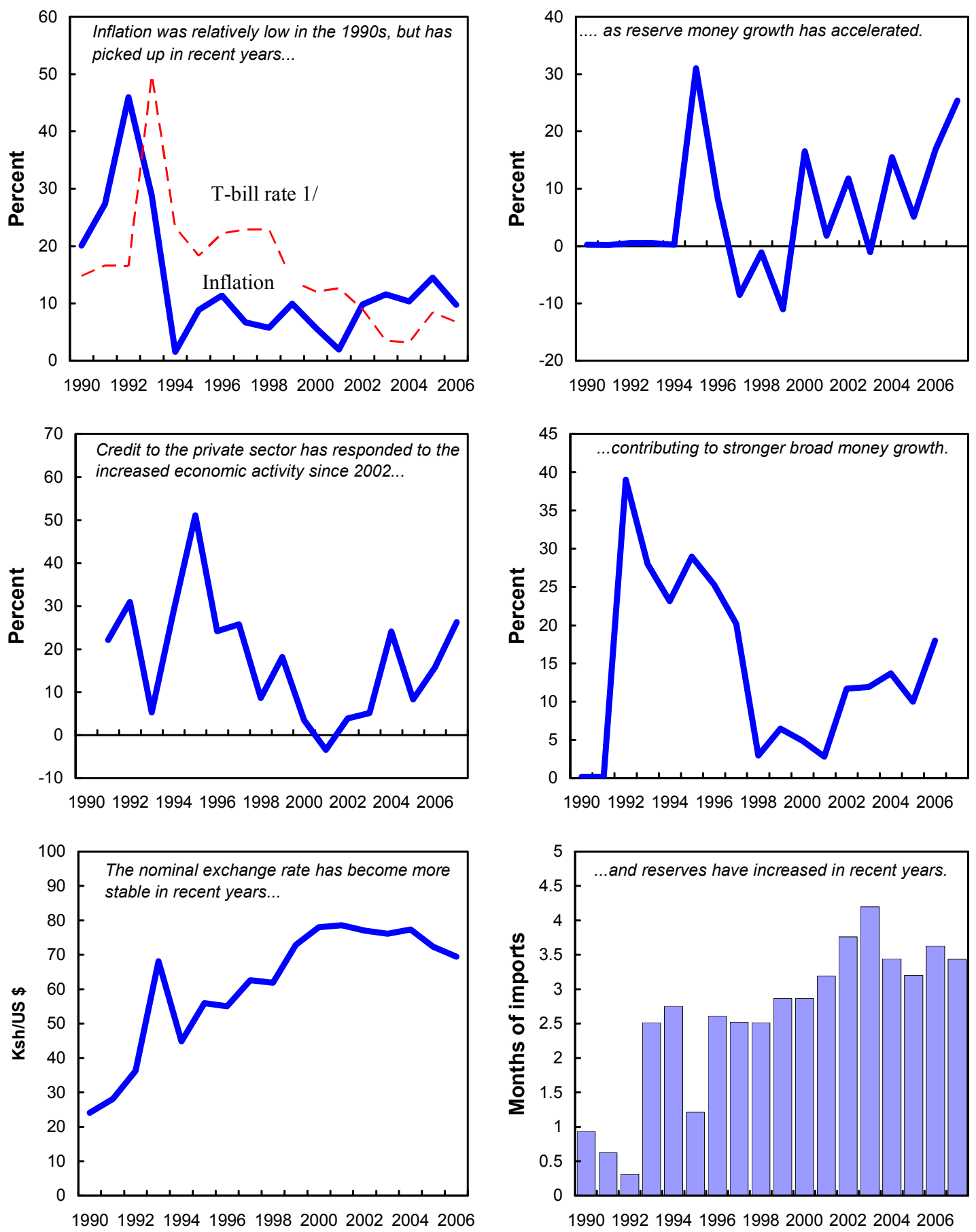

Sources: IMF, International Financial Statistics; Kenyan authorities, and staff estimates and projections.

1/ T-bill rate is for 3-month securities. 
appointed the director of the local branch of Transparency International as head of a new Office of Governance and Ethics (OGE), established a high-level judicial commission to reopen Goldenberg, and hired the investigation firm Kroll Associates to track Moi-era funds.

\section{Optimism that the new administration would tackle governance was dented by} the Anglo-Leasing affair, which emerged in 2004 (Box 2). Donors again froze aid to the government, but the authorities pressed ahead with reforms aimed at improving the efficiency of the public sector and supporting private-sector growth. Donor support remained at around 2 percent of GDP, compared to 10 percent of GDP in Tanzania and Uganda, and net foreign financing to the budget continued to be negative.

\section{Box 2. The Anglo-Leasing Affair}

Anglo-Leasing involved 18 fraudulent or flawed security contracts, with payment for goods that were overpriced or not delivered. The contracts totaled approximately $\$ 750$ million and were agreed during 1997-2004. Six contracts amounting to over $\$ 300$ million were awarded under the Kibaki administration in 2003-04, undermining the new administration's standing with the public and donors. Some contracts were cancelled, while funds were recovered in others. The problem was spotted in early 2004 by midlevel civil servants and was investigated by the Controller \& Auditor General, the Kenya Anti-corruption Commission (KACC), and the OGE. Mr. Githongo, the OGE director, resigned over slow progress in the case, and a memorandum from him to President Kibaki was leaked in early 2006. The memorandum gave a detailed account of Mr. Githongo's repeated attempts to follow up on the case and implicated the vice president and the justice, finance, and transport ministers. As with Goldenberg, prosecution of allegedly culpable high-level officials has not occurred. Three former permanent secretaries and others were charged in connection with the contracts and are currently in court.

13. Growth picked up from 2003, and policies remained relatively sound. Structural reforms carried out in the 1990s (e.g., public enterprise reforms) helped lay the foundation for this growth pick-up. Increased confidence, which many observers attributed to reduced government interference in business affairs and improved perceptions of political risk, contributed to higher private inflows, along with a more favorable external environment (see table below). However, inflows and limited appreciation led to looser-than-envisaged monetary policy and a pickup of inflation. Fiscal policy continued to be prudent, and enhanced operations of the Kenya Revenue Authority (KRA) increased revenues. A lower interest bill helped limit recourse to domestic financing and poverty-reducing spending increased by 2 percentage points of GDP, supporting the introduction of free primary education and higher outlays in health and agriculture. ${ }^{7}$ Infrastructure spending also increased, but remained well below levels in Tanzania and Uganda (see chart below). GDP growth in Kenya finally matched that in Tanzania and Uganda in 2006. Even so, Kenya's

\footnotetext{
${ }^{7}$ The pick-up of growth helped reduce poverty. According to the World Bank, a recent analysis of Kenya Income and Household Budget Survey data showed that the rate of absolute poverty declined from 52.3 percent in 1997 to 46.1 percent in 2005/06, with sharper declines in urban areas (from 49.2 percent to 38.8 percent) than in rural areas (52.9 percent to 49.1 percent). Inequality remained high, however, and increased in urban areas.
} 
Kenya: Selected BOP Inflows and Gross Reserves: 1993-2007

(Annual averages in US\$ millions)

\begin{tabular}{lcccc}
\hline & $1993-97$ & $1998-2002$ & $2003-07$ & 2006-07 \\
& & & & \\
\hline Private transfers (net) & 327 & 617 & 1,363 & 1,836 \\
Foreign direct investment flows & 18 & 66 & 364 & 722 \\
Commercial banks (net) & -8 & -39 & -101 & -141 \\
S-T (net) and net errors and omissions $1 /$ & 330 & 365 & 217 & 635 \\
Gross official reserves 2/ & 788 & 1,067 & 3,355 & 3,355 \\
Memo items: & 100 & 314 & 478 & 597 \\
Tanzania FDI & 112 & 169 & 317 & 392 \\
Uganda FDI & \multicolumn{4}{l}{} \\
\hline Source: IMF staff & & & \\
1/ This entry is believed to include under recorded tourism earnings. \\
2/ Amount of gross reserves at the end of 1997, 2002, and 2007, respectively.
\end{tabular}

apparent potential for higher growth than its neighbors - in terms of educational attainment, entrepreneurship, and institutional and physical infrastructuresuggests that considerable growth potential was squandered in the 1990s and early 2000s due in some measure to governance weaknesses. ${ }^{8}$

\section{The authorities also made} progress with structural reforms and governance legislation and institutions. Parastatal reforms included concessioning of the railways, the privatization of electricity generation, telecoms, and sugar companies, and performance contracts for all parastatals. These efforts broadened

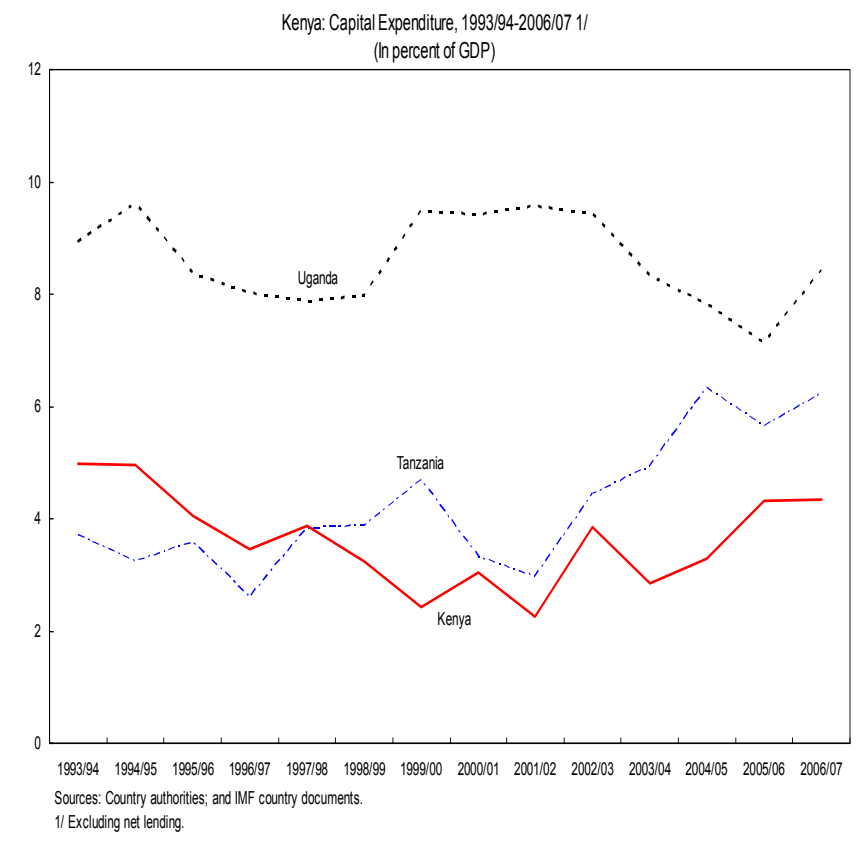
ownership and set the basis for potential improvements in performance. Business and regulatory reforms focused on elimination of licenses, a government-initiated effort that earned international recognition and may have significant impacts on business costs over the medium term, if sustained and deepened. In the governance area, new legislation was enacted in public ethics (e.g., wealth declaration), PFM and oversight, and procurement.

\footnotetext{
${ }^{8}$ World Bank statistics show, for example, considerably higher education spending levels and higher school enrollment at the primary, secondary, and tertiary levels in Kenya than in Tanzania or Uganda during 1985-2006, with some catch-up at the primary level (and the tertiary level for Uganda) in recent years.
} 
Transparency was enhanced through publication of procurement transactions, including in the security area, and court reforms advanced. ${ }^{9}$ While governance concerns remained, a perception emerged that corruption was no longer as pervasive, particularly at low levels. This was reflected in the acceleration of growth and investor interest and improved scores on some corruption and ease-of-doing-business indices.

15. Financial sector vulnerabilities and depth were addressed through reforms of the supervisory and regulatory framework. Compliance with prudential regulations improved, and non-performing loans (NPLs) declined from over 60 percent in 2003 to 23 percent in 2007 . Continuing weaknesses were shown, however, by recent difficulties in closing a small bank allegedly engaged in money laundering. KCB received a capital injection in 2003 and was restructured. State shareholding in the bank was reduced, although the government still retains the largest bloc of shares and guides strategic decisions. The NBK was placed under statutory control of the CBK in 2007 and recapitalized.

16. Kenya's exports increased sharply in recent years. Exports grew by $13 \frac{1}{2}$ percent per year in dollar terms over the past five years, compared with less than 5 percent annually during the previous decade (see chart below). Gains were made in diversifying exports, as coffee and tea made up one-fifth of exports of goods in 2007, down from over 40 percent in 1993. Service exports boomed.

\section{FUnd RELATIONS}

\section{During 1993-2007, Kenya was engaged in a continuous succession of Fund} arrangements. Programs agreed in 1996, 2000, and 2003 went off-track quickly. No reviews were completed under the 1996 or 2000 arrangements. Completion of the first and second reviews under the 2003 PRGF required 13 and 28 months, respectively (Table 1). The third review was completed in seven months.

\section{Response to the 1993 crisis}

18. With mounting external arrears and inflation, and pressures on the shilling, a six-month SMP from April 1993 and a one-year arrangement under the Enhanced Structural Adjustment Facility (ESAF) approved that December sought to restore stability. It became clear only later that pressures were linked in large part to Goldenberg. SMP and ESAF measures included price decontrol, reduction of the civil service, actions to improve parastatal finances, and initial privatizations. Governance actions were initially

\footnotetext{
${ }^{9}$ PFM improvements also included a more streamlined budget process and introduction of a medium-term expenditure framework. The number of benchmarks met under the Public Expenditure Management Assessment and Action Plan framework increased from 3 in 2003 to 10 in 2007.
} 
Kenya: Exports of Goods and Services and Coffee and Tea Prices 1993-2007

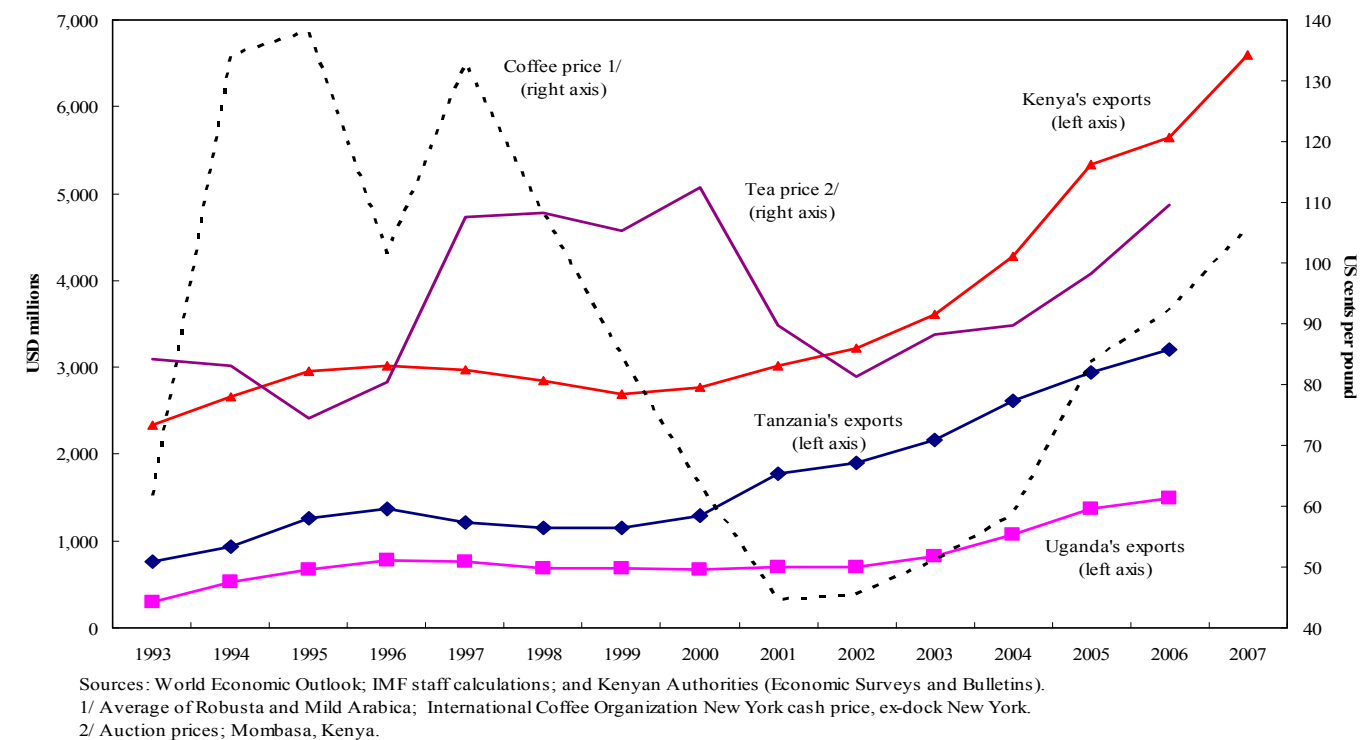

Table 1. Fund Arrangements with Kenya, 1993-2007

\begin{tabular}{|c|c|c|c|c|c|}
\hline $\begin{array}{c}\text { Arrangement / } \\
\text { review }\end{array}$ & $\begin{array}{l}\text { Approved/ } \\
\text { completed }\end{array}$ & $\begin{array}{l}\text { Original } \\
\text { Amount }\end{array}$ & $\begin{array}{l}\text { Augmentation } \\
\text { or Reduction }\end{array}$ & Disbursed & $\begin{array}{l}\text { Length } \\
\text { (months) }\end{array}$ \\
\hline 1993 ESAF & $12 / 22 / 1993$ & $\begin{array}{l}\text { SDR } 45.2 \text { million } \\
\text { (16.7 percent of } \\
\text { quota) }\end{array}$ & & SDR 22.6 million & 12 \\
\hline $\begin{array}{l}\text { First review } \\
\text { End of arrangement }\end{array}$ & $\begin{array}{l}11 / 21 / 1994 \\
12 / 21 / 1994\end{array}$ & & & SDR 22.6 million & 11 \\
\hline 1996 ESAF & $4 / 26 / 1996$ & $\begin{array}{l}\text { SDR } 149.6 \text { million } \\
\text { (55 percent of } \\
\text { quota) }\end{array}$ & & SDR 24.9 million & 36 \\
\hline $\begin{array}{l}\text { First review } \\
\text { End of arrangement }\end{array}$ & $\begin{array}{c}\text { Not completed } \\
4 / 25 / 1999\end{array}$ & & & & \\
\hline 2000 PRGF & $8 / 4 / 2000$ & $\begin{array}{l}\text { SDR } 150 \text { million (55 } \\
\text { percent of quota) }\end{array}$ & $\begin{array}{l}\text { SDR } 190 \text { million ( } 70 \\
\text { percent of quota) } 1 /\end{array}$ & SDR 33.6million & 36 \\
\hline $\begin{array}{l}\text { First review } \\
\text { End of arrangement }\end{array}$ & $\begin{array}{c}\text { Not completed } \\
8 / 3 / 2003\end{array}$ & & & & \\
\hline 2003 PRGF & $11 / 21 / 2003$ & $\begin{array}{l}\text { SDR } 175 \text { million (64 } \\
\text { percent of quota) }\end{array}$ & $\begin{array}{l}\text { SDR } 150 \text { million (55 } \\
\text { percent of quota) } 2 /\end{array}$ & SDR 25 million & 36 \\
\hline First review & $12 / 20 / 2004$ & & & SDR 50 million & 13 \\
\hline Second review & $4 / 11 / 2007$ & & & SDR 37.5 million & 28 \\
\hline Third review & $11 / 16 / 2007$ & & & SDR 37.5 million & 7 \\
\hline Original end of arrangement & $11 / 20 / 2006$ & & & & \\
\hline Actual end of arrangement & $11 / 20 / 2007$ & & & & \\
\hline
\end{tabular}

Source: PDR MONA database.

1/ The Poverty Reduction and Growth Facility (PRGF)-supported arrangement totaling SDR 150 million was approved in August 2000, and modified and augmented by SDR 40 million in October 2000 in light of a severe drought

2/ Due to sharp rise in oil prices and drought, and induced food imports, Board approved SDR 50 million augmentation, from SDR 175 to SDR 225 million. Due to broad improvement in Kenya's economic performance and lower balance of payment needs, the Board subsequently approved a reduction in access from SDR 225 million to SDR 150 million.

directed at the major parastatals. Slow progress delayed the mid-term ESAF review by six months. During 1994, progressive revelations pointed to significantly larger-scale Goldenberg payouts. 


\section{The 1996 ESAF}

19. Negotiations on a follow-on, three-year ESAF languished through 1995 over concerns with lack of progress on corruption and disclosures of extrabudgetary spending. ${ }^{10}$ The atmosphere was often strained, and the Fund's mission chief was accused of interfering in Goldenberg trials by defense lawyers following a press conference in Nairobi in September. The ESAF was approved in April 1996, but donors remained guarded. ${ }^{11}$ The new arrangement incorporated a further tightening of the fiscal deficit, parastatal measures, continued efforts to recover misappropriated funds, and increased transparency in procurement and contracting of debt.

20. The 1996 ESAF went off-track quickly, and no reviews were completed. This occurred against a backdrop of heightened focus by the Bank and Fund on corruption. At the 1996 Annual Meetings, Bank President James Wolfensohn gave a speech on the "cancer of corruption," and the IMF Interim Committee called for a stepped-up fight against graft. Over the next year, both institutions developed new governance guidelines, the first for the Fund. In July 1997, Kenya's High Court ruled that the Goldenberg prosecutions could not go forward on procedural grounds, upsetting donors. Other financial irregularities emerged. ${ }^{12}$ The authorities' response was unconvincing, and donors again scaled back aid. Fiscal slippages took place ahead of the 1997 elections, including sharp wage hikes and weak enforcement of spending controls. A short SMP was agreed in 1998 and helped restore prudent policies, but efforts to bring the governance agenda back on-track failed. The ESAF arrangement expired in April 1999.

\section{The "Dream Team" and the 2000 PRGF}

\section{With the expiry of the 1996 ESAF, consideration was given to a follow-up} arrangement and a broadening of the governance agenda beyond individual corruption cases. The Fund's focus on Kenya during late-1998 and early-1999 was particularly intensive, with frequent informal country matters (ICM) sessions on Kenya at the Board. During a session in May 1999, Directors called for a more comprehensive approach to addressing corruption in Kenya, involving legal and institutional actions to strengthen transparency, accountability, and budget management, and measures to remove discretion and rent-seeking opportunities. In July, after extensive consultations, including with the Bank

\footnotetext{
${ }^{10}$ These included a presidential airplane and construction of a new airport in President Moi's home town.

${ }^{11}$ At a Consultative Group (CG) meeting in March 1996, bilateral donors expressed concern about noneconomic governance issues, including democratization of the political process and the rule of law. Many were reluctant to make new commitments of support.

${ }^{12}$ These included tax evasion at customs and procurement irregularities in energy and health.
} 
President and the Fund Managing Director, President Moi appointed the "Dream Team," a handful of technocrats from the private sector or abroad headed by Dr. Richard Leakey, a leading opposition figure. The Dream Team conducted intensive consultations on governance reforms with donors, and an agenda covering dozens of measures was developed.

22. A new arrangement under the PRGF was approved in August 2000 with governance reforms as its key pillar. At the core were two laws - a code of ethics bill and an anti-corruption and economic crimes bill — and establishment of a fully-effective anticorruption agency. Nineteen structural conditions focused on governance, and 70 anticorruption measures were also included in the Memorandum of Economic and Financial Policies (MEFP). The arrangement was approved just one month before issuance of a Fund guidance note on streamlining conditionality, and it was augmented in October to help deal with a severe drought.

23. Major setbacks emerged just weeks after the augmentation and a Paris Club rescheduling in November 2000. Parliament rejected the code of ethics bill and postponed consideration of the anti-corruption and economic crimes bill. The High Court ruled that Kenya Anti-corruption Authority (KACA) was unconstitutional. Parliament also passed the "Donde Bill," which regulated interest rates in the banking sector.

24. Two subsequent years of efforts to bring about the key anti-corruption measures failed. In March 2001, Dr. Leakey departed; in August 2001, parliament rejected a constitutional amendment creating KACA; and in November, the High Court ordered the Attorney General to stop prosecuting a high-profile fraud case. Elections in 2002 began to draw near, this time intensified by an uncertain succession to President Moi.

\section{A new start with a new administration?}

25. The December 2002 election victory by an opposition coalition opened a window of opportunity. The Fund quickly formulated an engagement strategy, and during the Board discussion of the 2003 Article IV consultations in May, Directors commended the new government for placing anti-corruption at the top of its agenda. The new parliament enacted the long-outstanding code of ethics and anti-corruption and economic crimes laws. A Financial Sector Assessment Program (FSAP) mission took place in July, and a safeguards assessment followed in September, finding improvements in controls at the CBK.

26. A new PRGF arrangement was approved in November 2003, accompanied by fresh donor pledges of $\$ 4.1$ billion, aimed at stepping up social and capital spending and reducing domestic debt. In approving the arrangement, Directors commended the authorities for maintaining stability under difficult circumstances and for initial progress in the governance area. The new program included a range of governance actions, including conditionality on the establishment of the KACC. Eleven other conditions targeted procurement, transparency, and other issues. Another Paris Club rescheduling took place in January 2004. 
27. The Anglo-Leasing case broke in mid-2004, intensifying the focus on corruption. Leading diplomats reacted strongly, accusing the administration of addressing governance only rhetorically and on paper. Some donors postponed budget support. Fund staff and management initially focused on provision of adequate resources to KACC to investigate the case, but also on "evidence of prosecutions in significant corruption cases." Four prior actions were set for the first review, including on annual declaration and verification of the assets of top officials.

28. The first PRGF review was completed in January 2005—a delay of six months, but the first Fund program review completed in ten years. Again, access was augmented, this time for the effects of higher oil prices and another drought. In approving the review, Directors warned that governance remained a serious concern.

29. The PRGF encountered problems almost immediately. In February 2005, the government's anti-corruption czar, John Githongo, resigned, and more donors announced suspension of financial support. Staff proposed a range of actions to demonstrate progress on governance, including completion of Anglo-Leasing investigations by the KACC, suspension of officials found to be involved in the case, strengthening the prosecutorial authority of the KACC, and increased transparency and oversight for procurement transactions. ${ }^{13}$

\section{Some progress was made during 2005, but the PRGF was derailed again by} political developments and a temporary suspension of new lending by the Bank. The Goldenberg Commission report was issued in October, and a referendum on constitutional change failed in November 2005, leading to the fracture of the governing coalition. The referendum was a major focus of attention, which may have contributed to delays in taking actions to complete the second review. The arrival of a new World Bank President in June 2005 led to a stepped-up global focus on corruption. In late-November, Bank staff indicated that continuation of Bank lending programs with Kenya would be contingent on significant progress in: (i) taking decisive steps to remove senior officials suspected of or under investigation for corrupt practices; (ii) confirmation of government support of legislation giving prosecutorial authority to the KACC; and (iii) development of effective mechanisms for handling issues raised by the Goldenberg Commission and another report on illegal acquisition of wealth. The Bank subsequently provided some support in 2006 (e.g., drought relief), but indicated that budget support remained on hold over governance concerns, including steps to strengthen prosecutorial authority. In January 2006, the Githongo memo on Anglo-Leasing was leaked.

31. At the 2006 Spring Meetings, the Bank proposed a governance mission to identify concerns and map a way forward. The Bank mission, with Fund participation,

\footnotetext{
${ }^{13}$ Other measures considered included improvements in the transparency of political party financing and actions to address issues raised by a special commission on controversial land transfers.
} 
took place in July and confirmed that some legal and institutional progress had been made, although the anti-corruption effort seemed to be losing steam. In October, Bank management indicated to the Fund that conferral of prosecutorial power to the KACC was not a "make-orbreak" issue. During a November mission, understandings were reached with Fund and Bank staff on a Governance Action Plan (GAP) for the remainder of the term of the Kibaki administration. The GAP targeted further improved public access to information, enhanced PFM and procurement reforms, stepped up investigation, prosecution, and court capacity, efforts to facilitate the recovery of stolen assets, and improved service delivery in key sectors.

32. The Bank's involvement helped the Fund move to a forward-looking, institutional approach on governance as embodied in the GAP. In November 2006, the PRGF was extended, with support from key donors. Still, the Bank's governance-related actions in late 2005 and 2006 were controversial. The authorities felt that the suspension of new lending and the diagnostic mission had singled out Kenya. The Bank was also seen as moving slowly and without a clear, overarching strategy, while its decision-making was perceived as highly centralized and difficult to predict. ${ }^{14}$

33. Further macroeconomic and governance developments facilitated completion of the second and third PRGF reviews in 2007. A substantial improvement of performance in Kenya coincided with greater emphasis by the Fund on macrocriticality of conditionality and suggested that governance may have indeed improved. Progress was made in procurement and PFM reforms. In approving the second review, Directors highlighted the link between governance and growth, and stressed the need to decisively address remaining weaknesses, particularly in providing resources to law enforcement, completing the legislative agenda on governance, and moving forward with investigation and prosecution of corruption cases. Following discussions with staff, the authorities requested a reduction of access under the PRGF at the time of the second review, consistent with the improvement in Kenya's external balance of payments situation. The arrangement was extended two more times - eventually to November 2007. In approving the third review, Directors again urged movement on highprofile prosecutions. With the forward-looking agenda on governance in place, the program placed more emphasis in 2007 on sustaining growth, poverty reduction, and improving infrastructure.

\section{KEY ISSUES IN FUND ENGAGEMENT}

34. The nature of Kenya's longer-term engagement with the Fund differed from the typical pattern for sub-Saharan Africa. Engagement was characterized by an extensive focus on governance and exceptional difficulty in completing reviews, but also relatively

\footnotetext{
${ }^{14}$ Appendix II provides a brief discussion of Bank relations with Kenya during the EPA period.
} 
sound macroeconomic policies, comparatively little donor assistance, and over time, progress on structural reforms.

35. For the Fund, Kenya's regional importance, a continuing policy agenda, and extensive donor involvement made disengagement unattractive, in spite of a mixed track record. For the international community, Kenya was regarded as a country of great potential and importance in East Africa. This was reinforced by conflicts in neighboring states and Kenya's stability and openness. The authorities' stabilization in 1993-94, cautious policy management, and gradual progress in some reform areas made engagement compelling. Donors maintained throughout the period that the Fund should stay engaged to help address deficiencies in governance and enforce accountability in corruptions cases.

36. From the Kenyan side, several factors motivated the long engagement. These included difficult economic conditions, the need for the Fund's "stamp of approval" for donors and Paris Club reschedulings, and a desire for policy advice. However, once programs were agreed and Paris Club deals were secured, ownership faded quickly. Implementation flagged repeatedly in the run-up to elections, a pattern that was broken in 2007. Observers have suggested that President Moi long sought to mitigate donor pressures by frequently changing tack (and ministers) and doing "just enough to get by." This became known as the "donors dance" and contributed to cynicism about Kenya in the international community.

\section{A. Policy Advice and Program Design in Core Macroeconomic Areas}

\section{Monetary policy and financial sector reforms}

37. Monetary policy advice and program design consistently aimed at achieving price stability. The SMP and ESAF in 1993-94 aimed to address crisis conditions by limiting access to CBK lending facilities. The ESAF set targets on net domestic assets (NDA) of the CBK, with a subceiling on credit to the government, while specifying an exchange rate band. This reflected the need to contain the major source of pressure on monetary aggregates - government financing - and Kenya's managed float exchange regime. By the late 1990s, program design was geared to accepting exchange and interest rate fluctuations. A floor on reserves was included in the 2000 and 2003 arrangements. After the first review of the 2003 PRGF, NDA targets were dropped in favor of reserve money ceilings.

38. While advice and program design appear to have been broadly appropriate, the response was complicated by competing objectives. After 1993-94, the CBK was reluctant to allow for significant upward interest rate flexibility, likely reflecting the government's de facto influence in interest rate policy and the large domestic debt burden. Combined with a desire for exchange rate stability, this meant that money growth was generally above 
program targets, particularly after 2003. Headline inflation increased, although underlying inflation remained broadly in line with the official

5-percent target. Real interest rates have been negative in recent years (see chart). ${ }^{15}$

39. Kenya's financial system is the most developed in the region, but has a history of weakness and stress; programs attempted to address these with mixed success. Fund arrangements continually aimed to strengthen the independence and oversight operations of the $\mathrm{CBK}$, to reform the two major state banks (NBK and KCB), and to modernize the legal and judicial system. The 1996 ESAF contained conditionality on legal

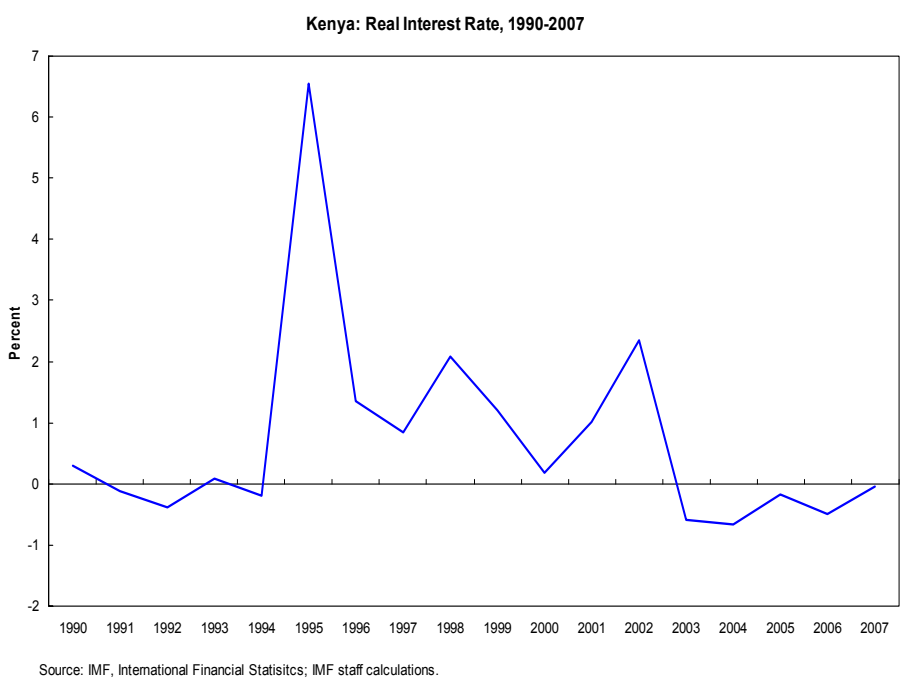
amendments to limit CBK credit to the government and establish greater security of tenure for the CBK governor. The program also targeted commercialization of KCB. The 2000 and 2003 PRGFs pressed for further amendments to the CBK Act and sale of a stake in KCB, as well as legal and procedural changes to address slow litigation on loan defaults. Measures under the 2003 PRGF included transfer of supervisory powers from the MOF to the CBK, a plan for restructuring the NBK, and introduction of anti-money laundering legislation.

40. While the focus of programs was appropriate, and some progress was achieved, CBK independence and the status of the NBK were not decisively resolved.

- During the 1990s, legislative reforms led to improvement in the CBK's supervisory framework, and some distressed banks were liquidated. Soundness indicators now point to a reasonably wellcapitalized, profitable, and liquid banking sector. NPLs were concentrated in the two large state banks and came down gradually. Compliance with prudential

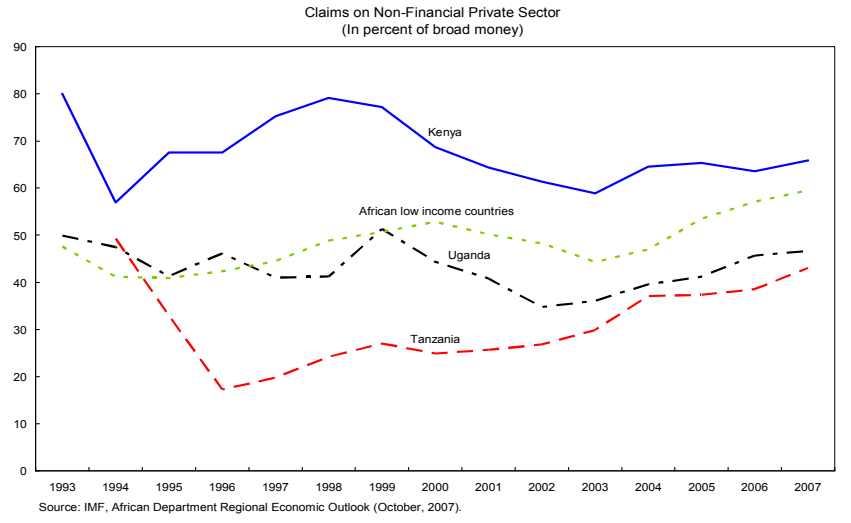
regulations improved, except for the NBK. KCB was restructured, and state shareholding reduced to 26 percent. Credit to the private sector picked up during the period of the 2003 PRGF, although it remained below levels of the mid-1990s, and the acceleration was less pronounced than elsewhere in the region (see chart). Corporates enhanced their access to

\footnotetext{
15 There are indications that the measurement of consumer price inflation in Kenya may be overstated due to methodological shortcomings; Statistics Department (STA) has been working with the authorities to assess these.
} 
long-term capital through issuance of commercial paper and bonds. However, high spreads continued, along with limited services and access for some market segments.

- Some gains were made in bolstering CBK independence. Concerns dated to Goldenberg and also reflected developments in interest rate policy and supervision. A key step was curtailing the CBK's lending to the government in 1996. More recent legal changes gave the CBK increased authority over the licensing of banks. However, past legislative regulation of interest rates and the CBK's reluctance to allow interest rates to increase due to fiscal implications suggest constraints on the CBK's autonomy in achieving price stability. Greater transparency about decision making processes and improved reporting would be helpful.

- Slow implementation and setbacks raised doubts about ownership. Programs struggled with legislative proposals to regulate banking fees and interest rates, and reforms of the NBK - first mooted in the early 1990s - did not advance until 2007, with recapitalization and a restructuring plan. ${ }^{16}$ From the Kenyan side, these developments were explained by concerns with costs and access to financial services by small and medium enterprises (SMEs), the manufacturing sector, and clients in rural areas. There was also slow movement on strengthening the National Social Security Fund (NSSF) and dealing with its contingent liabilities. Finally, gaps in the legal framework were exposed by recent challenges to the CBK's supervisory power by Charterhouse Bank, a small but solvent financial institution accused of violations of the Banking Act. ${ }^{17}$

41. Extensive TA appears to have been moderately effective. The last major diagnostic, the 2004 Financial Sector Stability Assessment (FSSA), found a persistence of weak financial institutions and provisioning requirements, lack of regulatory independence, and deficiencies in the legal framework, governance, and infrastructure, in spite of substantial technical support. The EPA team counted 54 TA missions during 1993-2007, including 34 on banking supervision and regulation and 11 on monetary operations. TA in monetary operations and foreign exchange management seems more evidently successful, having supported the development of indirect monetary instruments and operations and the transition to a managed float exchange regime.

\footnotetext{
${ }^{16}$ The NBK was placed under strict supervisory control of the CBK, and the CBK's autonomy and control will be important to ensure that the new capital is not lost through doubtful new lending.

${ }^{17}$ In addition, in late-2007, just after the conclusion of the PRGF arrangement, the MOF granted an exemption from ownership disclosures for a local bank that had attracted foreign investors. This may constrain the CBK's application of connected and insider lending and fit-and-proper rules and set a precedent.
} 


\section{Exchange rate policy}

\section{Exchange rate policy advice urged flexibility throughout the EPA period,} although the authorities favored greater stability and policies struggled with shocks and volatile capital inflows, particularly in the 1990s. This was recognized over time, and calls for flexibility became more nuanced, while concerns with competitiveness focused on business environment issues (i.e., governance, parastatal operations, infrastructure, insecurity, high unit labor costs, and wage pressures from the public sector) rather than the level of the exchange rate.

- A key achievement of the 1993 ESAF was the establishment of a unified exchange rate, with removal of surrender requirements and special facilities for oil imports. However, sharp fluctuations in capital flows - reflecting political developments, donor relations, domestic policies, and speculative flows - led to significant volatility of the shilling between early 1993 and mid-1995. Staff agreed with the desirability of a stable rate, but urged that it be market-determined and supported by policy actions. Capital outflows in 1993 gave way to sharp inflows in 1994, and the CBK responded with sterilized reserve accumulation, which led to a build-up of short-term debt and high real interest rates. In 1995, the CBK lowered interest rates to facilitate growth, leading to capital outflows, a loss of reserves, and rapid depreciation. The CBK again raised interest rates, and the shilling eventually stabilized. When pressures finally subsided in late 1995, the authorities argued for maintaining a stable shilling at a competitive rate, while staff noted that low reserves and prospects for continued capital flows called for acceptance of relatively large exchange rate fluctuations, with policies based on targeting monetary aggregates.

- The approval of the 1996 ESAF initially led to large inflows and some appreciation, but failure to complete the mid-term review in 1997 triggered reversals, intervention by the CBK, and sharp depreciation. The CBK hiked interest rates, and the shilling stabilized. Staff again warned that limited flexibility would encourage speculation. In 1999, following extensive CBK liquidity support for the NBK, reserves declined to just two months of imports, and the shilling depreciated.

- The 2000 PRGF targeted a gradual increase of reserve coverage to four months of imports. Although staff and the authorities again agreed that the shilling should be market-determined and flexible, the exchange rate remained at K Sh 79 per dollar during much of 2000-03, contributing to a deceleration of inflation. During this time, staff observed that the exchange rate was not the key factor for competitiveness and increasingly linked the acceleration of structural reforms and improvements in infrastructure to competitiveness concerns. For their part, the authorities developed a range of export incentives, including manufacturing under bond, export processing zones, and value-added tax exemptions. 
- $\quad$ The request for the 2003 PRGF indicated that the authorities would maintain the flexible exchange rate system (in spite of little movement of the nominal rate), and that intervention would aim to smooth short-term volatility, offset variability in donor flows, effect government debt payments, and meet reserve targets. Flexibility would come in response to medium- and long-term exogenous shocks, although these were not described. In recent years, the shilling was allowed to appreciate in nominal terms, although the authorities also made unsterilized foreign exchange purchases to alleviate pressures. This led to significant increases in reserve money growth. Staff continued to stress structural reforms as the way to address competitiveness concerns.

43. While the explicit focus on flexibility continued throughout the period, policy assessments reasonably took account of the difficulties in dealing with volatile capital movements, the authorities' demonstrated preference for stability, and Kenya's vulnerability to drought. This was reflected the progressively broader acceptance of factors for foreign exchange intervention and an increase in the suggested coverage of reserves from four to five months of imports after 2003. In addition, the contribution of stability to lower inflation from 1999 was noted, although staff also warned on risks of misalignment. To be consistent with the continued calls for flexibility (and the explicit characterization of Kenya's exchange regime as flexible), staff could have more critically analyzed the "remarkable stability" of the shilling, but exchange rate issues did not figure as prominently in Fund reports as other concerns, most notably governance, or fiscal and financial structural reforms. The approach was pragmatic and rightly focused on business environment issues to address competitiveness concerns, which were targeted by conditionality and covered extensively in Article IV consultations.

44. An analysis of the real effective exchange rate (REER) using monthly data for 1990-2007 suggests that movements have been broadly in line with the estimated equilibrium values during the period (see charts below). The shilling's variation was driven largely by productivity developments and terms of trade, with a period of significant overshooting during 1993-96, a period of turmoil in the foreign exchange market. In the past two years, the shilling has continued to appreciate, although this appears to be in line with fundamentals such as increased tourism receipts, remittances, and capital inflows.

\section{Trade policy and regional linkages}

\section{Trade policy advice and regional issues were not prominent under Fund}

arrangements. Staff argued for reduced tariff rates, consolidation of bands, and removal of discretionary authority. Progress was mixed, as rates were repeatedly adjusted up and down, while exemptions were introduced or eliminated depending on fiscal or weather conditions. Over time, progress was made in limiting government intervention and discretion in the key agriculture sector - both in terms of domestic and international trade. In recent years, greater attention was paid to regional issues, in the context of the East Africa Community (EAC), where Kenya took the lead in integration. When proposals were made to introduce an EAC 
Kenya: Exchange Rate Developments, 1990-2007
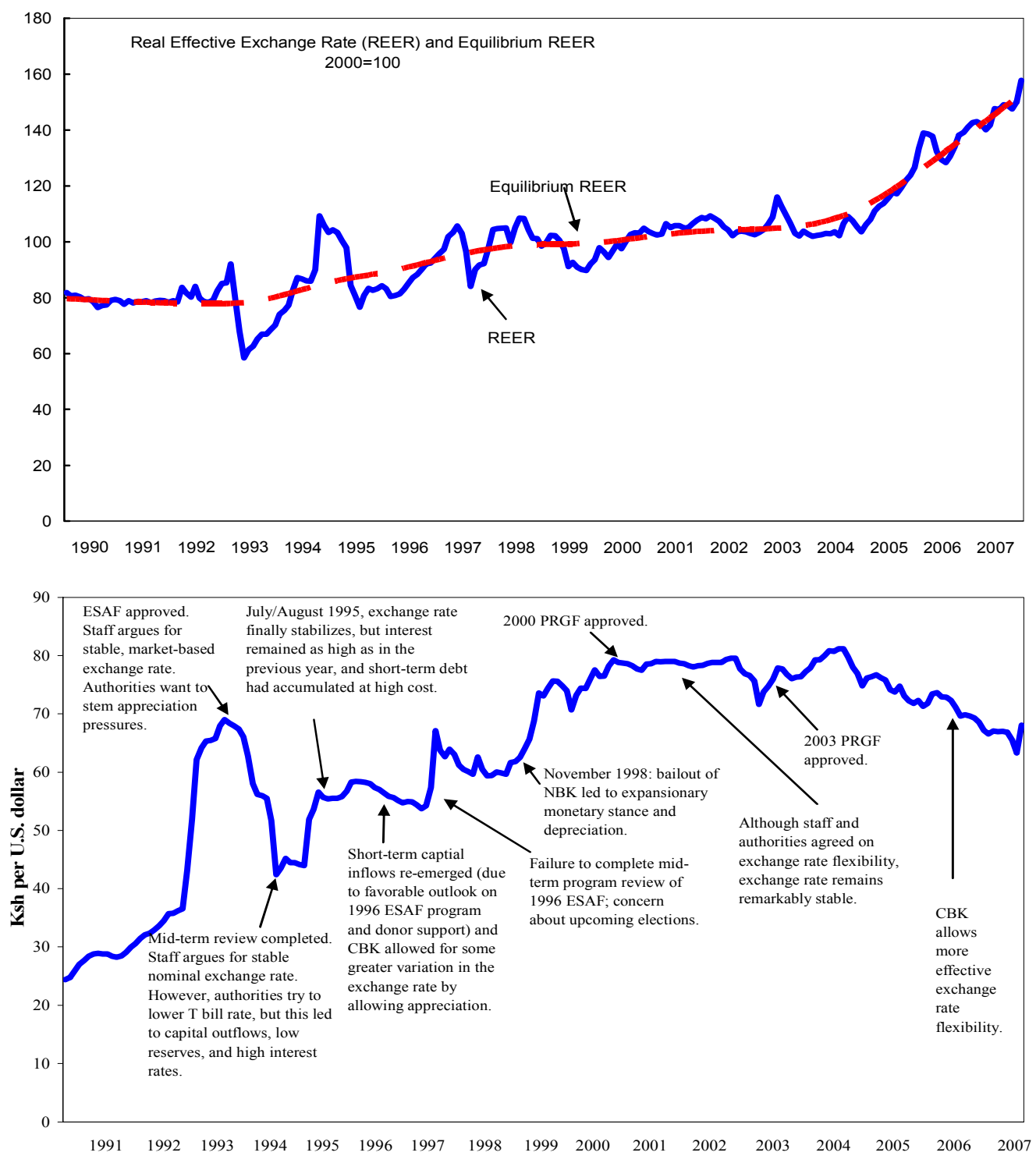

Sources: National authorities, and IMF staff estimates and projections.

monetary union, staff encouraged the authorities of the EAC countries (Kenya, Tanzania, and Uganda) to first aim to unify the regulatory framework. Given difficulties with keeping programs on-track and concerns in other areas, this limited focus was warranted. 
Fiscal policy and structural fiscal reforms

46. Fiscal targets under the first three arrangements aimed to limit demand pressures. Overall deficit targets (with limits on CBK financing) became increasingly tight during the 1990s, and although they were often missed, outcomes increasingly reflected tighter execution. The tightening may have continued for too long, however, given slowing growth. During 2000/012002/03, deficit targets were relaxed in anticipation of large donor inflows and may have become too loose, as domestic debt increased when aid did not materialize (see chart).

\section{Given high domestic debt and}

(In percent of GDP)

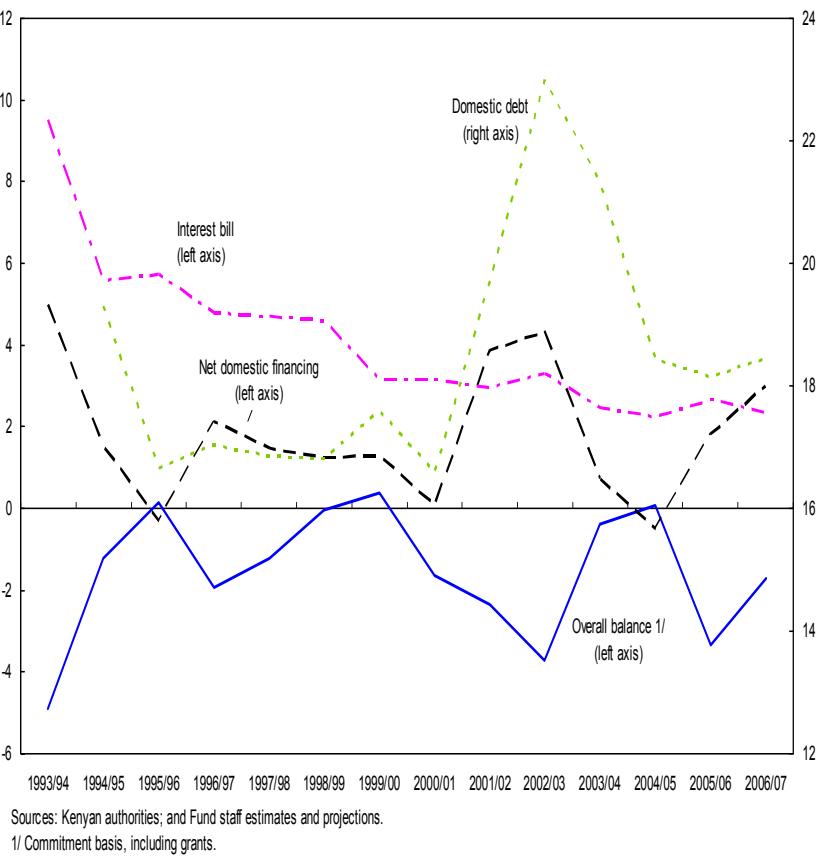
unpredictable external financing, targets appropriately shifted to net domestic financing (NDF) with the 2003 PRGF. Adjustors for arrears repayment, privatization receipts, and donor assistance were incorporated. The authorities adopted an approach to not program uncertain donor budget support to improve predictability. A zero ceiling on nonconcessional external borrowing was dropped at the time of the second review for the purpose of issuing a benchmark sovereign bond. The modest nonconcessional limit was reasonable, given established debt sustainability, and the authorities were rightly urged to first seek concessional donor support. Over the past five years, the program fiscal stance was broadly appropriate.

\section{An earlier focus on domestic debt consolidation and NDF targeting would have}

been appropriate. Debt sustainability was initially assessed only in relation to external debt, which generally posed low risk. In line with emerging Fund guidance, domestic debt sustainability was assessed in 2002 and later included in the debt sustainability analysis (DSA). NDF would have served as a useful target under the 2000 PRGF. Tighter control of domestic financing under the 2000 PRGF could have led to lower interest payments and helped improve spending efficiency.

\section{Two additional fiscal targets warrant discussion:}

- $\quad$ Reflecting large losses, the 1993 ESAF incorporated targets on the combined liquid assets and operating balance of major parastatals. These were dropped with the 1996 and 2000 ESAF, respectively, reflecting a return to a consolidated surplus. However, while parastatal reforms advanced, monitoring remained paper-based, and 
quantitative indicators could have been retained to enhance oversight. ${ }^{18}$

Conditionality in the 2003 PRGF requiring a study of parastatal liabilities was appropriate.

- The 2003 PRGF introduced targets on central government wages and salaries, although these were dropped with the second review. The targets, which excluded externally financed wages, were an appropriate response to chronic wage bill pressures, ad hoc wage hikes, and slow progress on civil service reforms since the mid-1990s. ${ }^{19}$ However, the rationale for the ceilings was not made clear to the public — nor was an adjustor for hiring health workers agreed during initial discussions on the second review. The ceilings were dropped when the review was completed. With the very long lag in concluding the review-nearly two-and-a-half years - and nonpublication of staff reports, NGOs still criticize the Fund on the wage ceilings, despite the exclusion of externally financed wages and the adjustors. The episode reflected poor public communications.

\section{Structural fiscal reforms and TA appropriately targeted modernization of} revenue administration and PFM. Revenue performance improved from 2000, due in part to reforms at the KRA. PFM reforms aimed to ensure better budgeting, more efficient spending, and resolution of such chronic problems as the periodic burst of spending arrears. ${ }^{20}$ Fund TA supported these reforms and became more intensive with the 2000 PRGF and particularly from 2003.

- In revenue administration, there was early and consistent TA engagement. Soon after the KRA was established in 1995, a resident advisor was placed for three years. TA focused on strategic issues and follow-up. A key factor in generally effective TA was responsive and professional KRA management, which had established credibility on corruption at an early stage. ${ }^{21}$ In addition, the KRA was established as an autonomous agency with its own funding - up to 2 percent of revenues, under the KRA Act. Fund TA was well-tuned to challenges and capacity, and there was substantial buy-in from the MOF, given the lack of external resources.

- $\quad$ Prior to 2000, PFM TA was relatively limited, in spite of the strong focus on governance. This apparently reflected a presumption of low effectiveness, as frequent

\footnotetext{
${ }^{18}$ See Appendix III for a discussion of public enterprise reforms in Kenya.

${ }^{19}$ See Appendix IV for a discussion of civil service reforms.

${ }^{20}$ The stock of arrears tracked electoral cycles, with spikes in 1992, 1997, and 2002. An audit of arrears under the 2003 PRGF found 95 percent of the claims fraudulent.

${ }^{21}$ In 1996, the heads of the KRA and customs were fired in a corruption scandal. In 1998, when the KRA took on a longstanding problem of tax evasion on sugar imports, the customs head was removed, but reinstated.
} 
PFM initiatives were short-lived and ineffective. For example, measures to hold ministerial accounting officers responsible for spending overruns were tried in 1993, 1996, and 2000. After 2000, PFM TA picked up, although in fairly narrow areas. ${ }^{22} \mathrm{~A}$ resident advisor was placed in 2001, but only for one year.

- $\quad$ PFM TA effectiveness improved in recent years. Assessment missions in 2003 and 2005 raised awareness of the need to address a backlog of reforms compared to other countries. A "Strategy to Revitalize PFM" was launched in 2006, and recent improvements included introduction of GFS2001-compatible classification, improved tracking of aid flows, preparation of a draft organic budget law, implementation of a new computerized information system, and preparatory work on program budgeting.

\section{B. Governance}

51. Governance was long the major focal point of Fund engagement in Kenya. Much of this can be traced to Goldenberg, and its size and significant fiduciary and reputational implications. The focus was sustained by the lack of high-level Goldenberg prosecutions, halting progress on anti-corruption measures, donor pressures, and other cases, including Anglo-Leasing. ${ }^{23}$ Governance indicators were among the world's lowest (Figure 5), and Kenya's weak growth performance through 2002 confirmed these concerns.

\section{Did the Fund have a clear and consistent strategy on governance in Kenya?}

\section{Fund guidance on conditionality developed over time and increasingly} emphasized streamlining, but allowed-and required-judgment as to whether proposed measures were critical to program implementation. Guidance stressed macroeconomic impacts and criticality to achieving program objectives. In the case of Kenya, anti-corruption conditionality was often justified by the impact that specific measures would have on unblocking donor financing. ${ }^{24}$ Defined this way, the range of possible measures could be quite broad (and subject to donor pressures). ${ }^{25}$

\footnotetext{
${ }^{22}$ For example, review of semi-autonomous agencies, tracking of donor flows, and strengthening legislation.

${ }^{23}$ Some have suggested that with greater press freedom and a more active political opposition and donor community, corruption simply was more visible in Kenya. It is noteworthy that whistle blowers and Kenyan audit and oversight institutions helped bring both Goldenberg and Anglo-Leasing to light.

${ }^{24}$ The Fund's Legal Department (LEG) confirmed in 1994 that a financing gap arising from donors' withholding of assistance was relevant for the Fund's assessment of Kenya's financial programs.

${ }^{25}$ The association of anti-corruption measures to growth was consistently noted by staff, particularly during the slowdown in the 1990s. Staff did not, however, link the slowdown in Kenya to a similar growth pattern observed throughout sub-Saharan Africa, but took flagging performance as a clear indication of the effects of poor governance. A more formal link was made with the 2002 and 2004 Article IV consultations, when papers on the association of governance and growth were issued.
} 
Figure 5. Kenya: Governance Indicators, 1996-2007
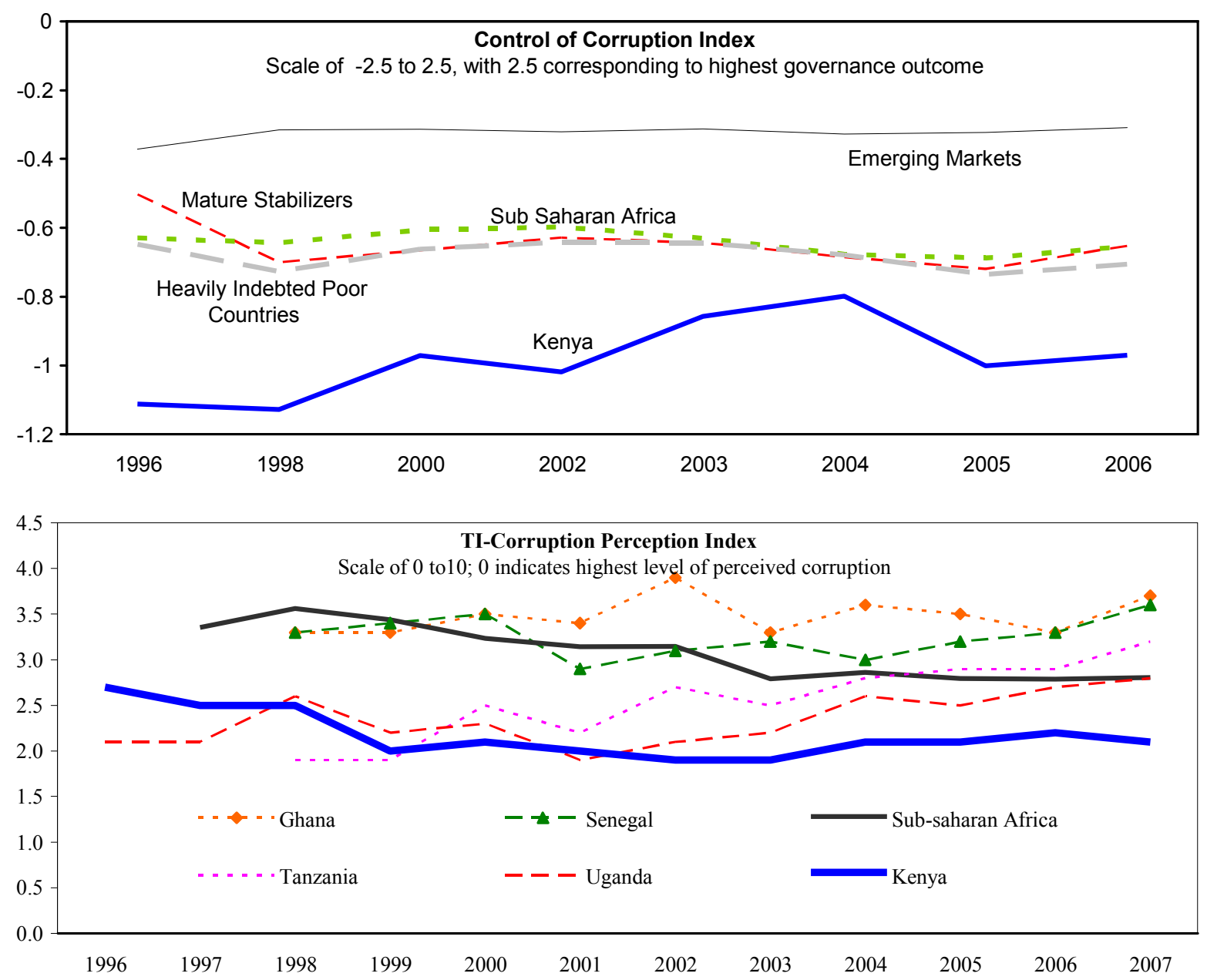

Sources: Transparency International; World Bank.

\section{In 1994 and 1995, LEG clarified that there should be no specific program} conditionality on the prosecution and imposition of criminal sanctions on officials alleged to be involved in Goldenberg. ${ }^{26}$ Fund strategy therefore focused on legal and institutional reforms to reduce the likelihood of future losses and on the authorities' efforts to recover Goldenberg funds. It was also recognized, however, that donors might withhold assistance to Kenya, if actions to establish accountability were viewed as insufficient. The

\footnotetext{
${ }^{26}$ Specifically, LEG noted that since the officials involved in the past abuses had ceased to hold office, there was no longer a risk of a continuation of those abuses. In this context, LEG found that such specific program conditionality on the prosecution and imposition of criminal sanctions on these officials would not have been relevant either for the implementation of the program or for the safeguarding of Fund resources.
} 
authorities were therefore urged by the Fund to press ahead with investigation and prosecution. Criminal cases were lodged against some senior treasury and CBK officials, as well as individuals from the private sector. These cases proceeded slowly, however, and after the High Court's suspension of the Goldenberg trials in July 1997, Fund strategy and conditionality moved to incorporate the creation of a strong, independent anti-corruption agency with prosecutorial authority. This brought limited success and considerable frustration. The core concern with prosecution remained through the end of the EPA period.

\section{Reflecting uneven ownership and a mixed track record, governance} conditionality at times became reactive, with some measures having tenuous links to macroeconomic objectives or appearing to be outside the Fund's core expertise. At points in the EPA period, measures were added, extended, or modified when agreed actions were incomplete or new developments occurred. This led to perceptions on the part of the authorities of "shifting the goalposts" and micromanagement by the Fund. While staff was right to monitor events closely and to exercise careful judgment on satisfactory implementation of agreed measures, at times the Fund became overly reactive to events on the ground, likely catalyzed in part by pressures and second-guessing from donors and other parties (Box 3). Instead, a strategic reappraisal or refocusing by the Fund on a narrower set of objectives was warranted.

\section{Specific guidance on governance was adopted by the Board in 1997, long after}

Goldenberg. A 1997 good governance guidance note indicated that conditionality related to economic aspects of governance could be agreed, if needed to meet program objectives due to direct macroeconomic impacts. If measures were not critical for program success, but donors reduced their support absent action by the authorities, the Fund might still withhold support if the required adjustment (without donor support) was not feasible. The note emphasized that the Fund staff should develop an independent view of the macroeconomic implications of lower donor support in the short and medium term, and exercise independent judgment in formulating policy advice. Staff should raise individual instances of corruption, if there is reason to believe these could have significant macroeconomic implications. The note outlined possible actions, including: changes in management of public institutions; removal, as appropriate, of individuals from involvement in particular operations where corruption had occurred; and, efforts to recover misappropriated funds. Staff was advised to avoid actions prejudicial to domestic legal processes in particular cases. The Board reaffirmed the note in 2001, although Directors called for further efforts to apply the test of macroeconomic relevance and emphasized evenhandedness, ownership, and prevention.

56. Programs became overloaded. In 1995, Fund management observed to staff that the agenda for the 1996 ESAF could severely strain the authorities' capacity, yet the number of conditions under programs with Kenya was higher than average. The number of conditions in the 1996 ESAF and 2000 PRGF - the latter with dozens of additional governance measures in the MEFP — was exceptionally high (see table below). Governance conditions in the 2003 


\section{Box 3. Actions to Bring the 1996 ESAF Back On-Track}

The 1996 ESAF went off-track quickly and was never revived. It provides an example of the difficulties faced in moving forward on the governance agenda, due to uneven ownership and changing events on the ground in Kenya. Actions to bring the program back on-track included:

- August 1996. Two prior actions to complete the mid-term review were: (i) parliamentary review of Goldenberg-related payments; and (ii) an audit of Ministry of Health drug purchases.

- December 1996. Seven prior actions included one related to the August 1996 Ministry of Health measure and new measures to address flawed electricity contracts.

- July 1997. Agreement could not be reached, and the first annual ESAF arrangement lapsed. A sticking point was a staff recommendation that disciplinary action be taken against former high officials not yet charged in the Goldenberg case. The Attorney General (AG) asserted that action could not be taken, lest ongoing cases be prejudiced.

- August 1997. New actions were agreed after the High Court suspended the Goldenberg trials, including: (i) renegotiation of the flawed power contracts; (ii) safeguarding the independence of the KRA; (iii) establishment of KACA and promulgation of regulations to establish procedures for creating an independent committee to advise the president on the appointment of the KACA director and assistant director; and (iv) preparation by the AG of a report to establish the accountability of officials associated with certain Goldenberg payments.

- February 1998. The KACA advisory committee was named before regulations requiring consultations with civil society on its appointment were issued. Staff asked that the regulations be issued and selection of the KACA advisory committee and management be re-run.

- June 1998. Same four actions from August 1997, with mixed progress. The president and the finance minister noted publicly the importance of safeguarding KRA's autonomy. However, the renegotiation of power contracts was incomplete; the KACA advisory committee regulations were prepared, but not issued, and reappointment of committee members was problematic. No progress was made in producing the AG's Goldenberg report.

- September 1998. Same four actions, with three nearly met. The AG's report-the second such report-was completed, but considered inadequate. KACA draft regulations also had shortcomings, and the authorities agreed to reappoint advisory committee members, but without changes to the regulations.

- March 1999. One action remained: reappointment of KACA management. The AG's report was satisfactorily revised, but both sides agreed that it should not be published, lest it prejudice ongoing cases.

- April 1999. The ESAF expired.

- May 1999. Actions met (now to initiate discussions on a new ESAF), but the Board expressed concern with the "formalistic" nature of implementation and recommended postponing discussions. 
Conditionality Under Fund Supported Programs

(Per program year)

\begin{tabular}{|c|c|c|c|c|c|c|c|}
\hline \multirow[b]{2}{*}{ Kenya } & \multirow{2}{*}{$\begin{array}{c}\text { Prior } \\
\text { actions }\end{array}$} & \multirow[b]{2}{*}{ SPCs } & \multirow[b]{2}{*}{ SBMs } & \multirow[b]{2}{*}{ Total } & \multicolumn{3}{|c|}{ Fund Average } \\
\hline & & & & & Year* & PRGF & PRGF/GRA \\
\hline 1993-94 ESAF & 0 & 3 & 6 & 9 & 1995 & 9.1 & 11.4 \\
\hline 1996 ESAF & 10 & 5 & 7 & 22 & 1996 & 13 & 12.7 \\
\hline 2000 PRGF & 3 & 4 & 15 & 22 & 2000 & 13.1 & 17.5 \\
\hline 2003 PRGF & 3 & 5 & 7 & 15 & 2003 & 13.7 & 17.7 \\
\hline 1st Review (2005) & 4 & 5 & 6 & 15 & 2005 & 13.4 & 17.8 \\
\hline 2nd Review (2007) & 2 & 6 & 9 & 17 & 2006 & 20 & 19.4 \\
\hline
\end{tabular}

* Fund averages for 1994 and 2007 were not available.

Source: MONA, Fund staff reports

PRGF were initially more streamlined, but became more numerous and wide-ranging in the wake of Anglo-Leasing, as the Board urged additional governance measures in the context of the first review. Some staff and the authorities consider that the heavy focus on governance measures diverted attention from other core policy areas. This was particularly true for the small Dream Team, which confronted a hostile bureaucracy. Work in 2006 on the GAP also taxed counterparts at the ministries of finance and justice. A possible consequence was that Kenya lagged other countries in the region in key reform areas (e.g., PFM), while povertyreduction (and equity) issues received less-than-desirable attention in programs. Box 4 provides an assessment of conditionality in areas other than governance.

\section{Were opportunities to change the approach taken? Was there flexibility?}

\section{Three opportunities to change the dynamic of the engagement on governance} were presented, in 1999 with the Dream Team, in 2003 with the arrival of the Kibaki administration, and in 2005-06, in the wake of Anglo-Leasing. The Dream Team-era began with a promising start, but the Fund, donors, and the team overreached, aiming to put in place too many governance measures to "tie hands," with little high-level ownership or trust. ${ }^{27}$ A more focused, confidence-building approach might have been employed, although ownership and commitment at the highest level were lacking, while skepticism in the donor community ran very high. Under the 2003 PRGF, both sides were eventually able to reassert a new, forward-looking strategy targeting institutional improvements. At least four factors helped underpin this change: (i) the focus in the Fund on streamlining, parsimony, and

\footnotetext{
${ }^{27}$ See Appendix V for a discussion of measures proposed at that time.
} 


\section{Box 4. Structural Conditionality Outside of the Governance Area}

Although the key focus of conditionality under Fund arrangements with Kenya was on governance measures, programs also incorporated conditionality in other structural areas:

The 1993 ESAF included conditionality on maintaining positive real interest rates (via bids in t-bill auctions), retrenching civil servants, and reducing costs at the National Cereals and Produce Board (NCPB). Other measures targeted elimination of surrender requirements, and decontrolling maize and fuel prices. Conditionality was appropriately parsimonious, well-targeted to monetary and fiscal issues, and observed with few delays.

Conditionality in the 1996 ESAF targeted parliamentary submission of amendments to the CBK Act, divesting nonstrategic parastatals, cost-cutting and other measures at key parastatal—Kenya Post and Telecommunication Corporation (KPTC), Kenya Railway (KR), Kenya Power and Lighting Company (KPLC) - and further retrenchment of civil servants. The program also called for maintaining liberalized prices, converting the NSSF into an autonomous pension fund, and commercializing the NCPB.

Although no reviews were completed, conditionality on the CBK Act was successful in laying the basis for greater central bank independence (including by limiting budget financing). However, measures to strengthen banking supervision and monetary operations could also have been included.

The 2000 PRGF incorporated several financial sector conditions, including amendments to the Banking Act to control fraud, issuing of prudential regulations, reviewing deposit insurance, strengthening CBK supervisory authority, and privatizing KCB. Structural fiscal conditionality targeted the improvement of expenditure commitment and control, reducing arrears, improving pay for external audit staff, timely submission of audited accounts to parliament, and reforming internal audit. Other conditions focused on tariff reform and elimination of public sector import exemptions. The financial sector conditions were appropriate in focus, but lacked parsimony. Fiscal conditionality focused more on administrative measures than in the 1993 and 1996 ESAF arrangements, and limited success was achieved.

Under the 2003 PRGF, financial sector conditions aimed to strengthen CBK regulatory and supervisory powers, maintain market-based interest rates, and plan for NBK privatization and limit its overdraft at the CBK. Fiscal conditions targeted an elimination of arrears, a reform of public sector wage-setting, timely fiscal reporting and external audits, improving expenditure commitment controls, strengthening capacity at the finance ministry, medium-term expenditure framework reform, simplifying customs systems, improving procurement, implementing the Integrated Financial Management Information System, and making tax waivers more objective. Still other conditions concerned audits and restructuring of the NSSF, improved transparency of privatization, assessing parastatal liabilities, and eliminating business licenses. Once again, conditionality focused more on administrative than policy measures; this facilitated a better track record.

Over the EPA period, conditionality in nongovernance areas shifted from politically sensitive reforms to administrative measures. Given extensive governance measures, overall conditionality did not become more parsimonious. Nongovernance measures were generally in core Fund areas, and the focus on a few core policy measures in the earlier programs (civil service staffing, parastatal reforms) helped improve fiscal outcomes. The shift to more administrative measures, particularly from the 2000 ESAF, coincided with extensive and sensitive conditionality in the governance area, and may have reflected the need to avoid further overloading programs and capacity. Administrative measures facilitated a somewhat better track record, but also tackled problems less forcefully. As a result, irreversible progress in some key fiscal and financial sector reform areas remained outstanding. 
macrocriticality; (ii) Kenya's improved performance; (iii) the authorities' greater commitment to pursue structural and institutional governance reforms; and (iv) the engagement of the Bank on governance. The Fund showed greater pragmatism in late 2006 and early 2007 by moving away from the long insistence on independent prosecutorial authority for the KACC — if not prosecution — on the basis of the GAP.

\section{Were there positive outcomes from the anti-corruption focus?}

58. There were legal and institutional gains on governance during the EPA period.

Recent assessments indicate improvements, including the fiscal transparency ROSC and the Bank's Doing Business and Global Integrity reports. A functioning KACC was put in place; CBK safeguards seem to be working (likely prompted, in part, by the Fund's safeguards assessment efforts), with improved accounting, internal controls, external audit and transparency; and there were governance-related improvements in expenditure commitment control and procurement, revenue administration, parastatal operations, and the business environment. Many of these gains reflected program conditionality, albeit often with long lags. However, the long, core focus on high-level prosecution brought few visible results and strained relations.

59. It is difficult to say whether an earlier focus on other governance areas - such as PFM, transparency, and regulatory and business reforms, where recent steps supported the growth pickup - would have paid off. Hindsight suggests that earlier attention to PFM measures, particularly related to procurement, debt management, and transparency and audit institutions, may have limited the Anglo-Leasing scandal. However, donor concerns with prosecution could not be ignored, and prior to 2003 the track record in these other areas was uneven. After 2003, program ownership improved, the external environment strengthened, and - as suggested by surveys, indicators, and for example, the leaked Kroll report - there was less high-level interference and involvement in the business environment.

\section{Donor Relations}

60. Kenya's relations with the donor community were often stormy, complicating Fund engagement and program design. Ambitious donor commitments led to overly optimistic baseline projections of budgetary support. ${ }^{28}$ This finally improved with revisions to the 2003 PRGF arrangement (Figure 6). In addition, donor governments played a strong role in shaping Fund engagement, especially through frequent informal sessions at the Board. For example, donor skepticism led to close Board oversight of the 1996 ESAF. ${ }^{29}$ In 1998-99,

\footnotetext{
${ }^{28}$ See Appendix VI for a review of the timeline of donor support to Kenya.

${ }^{29}$ Directors called on staff to "provide quarterly reports to the Executive Board either in a written statement or in an oral presentation."
} 
Figure 6. Program vs. Outturn, Program Support, 1993/94-2006/07

(In percent of GDP)

Despite ambitious commitments from donors, and optimistic projections, donor support was low and program projections proved unrealistic.
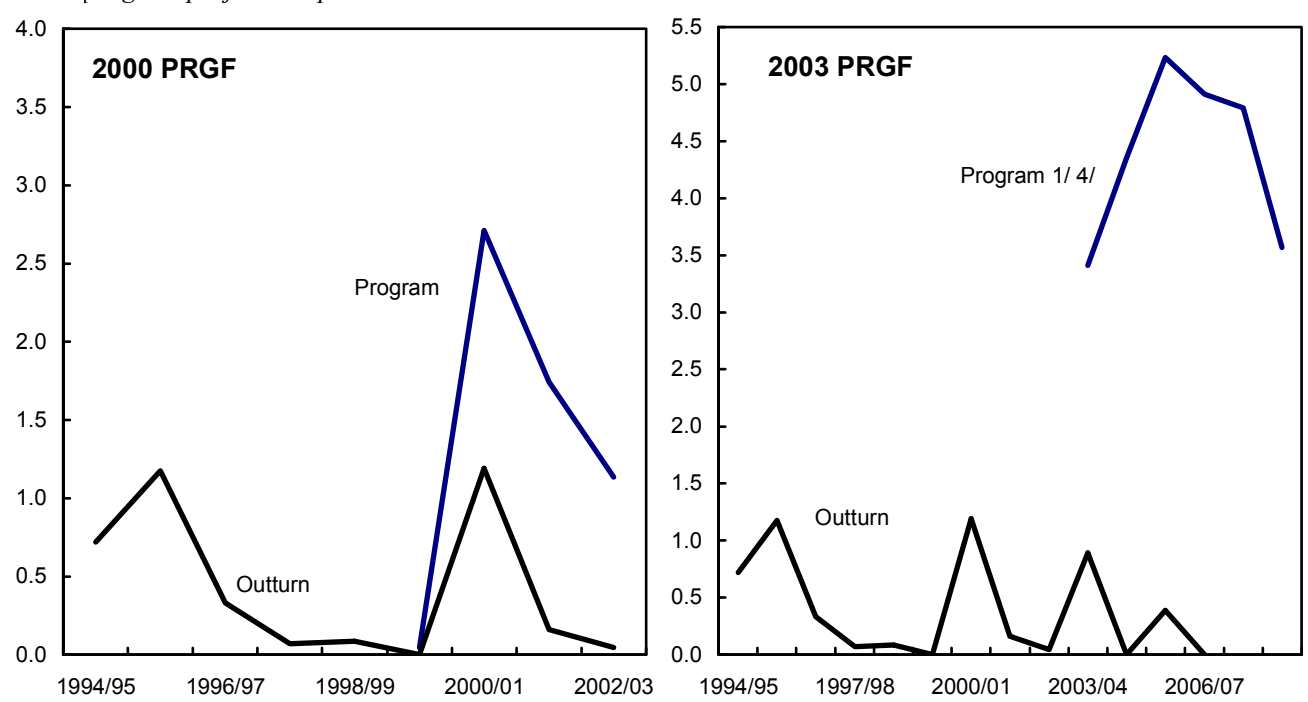

Subsequent program updates did not well take into account past experience with disbursements of budget support, although this improved with 2003 PRGF program updates.
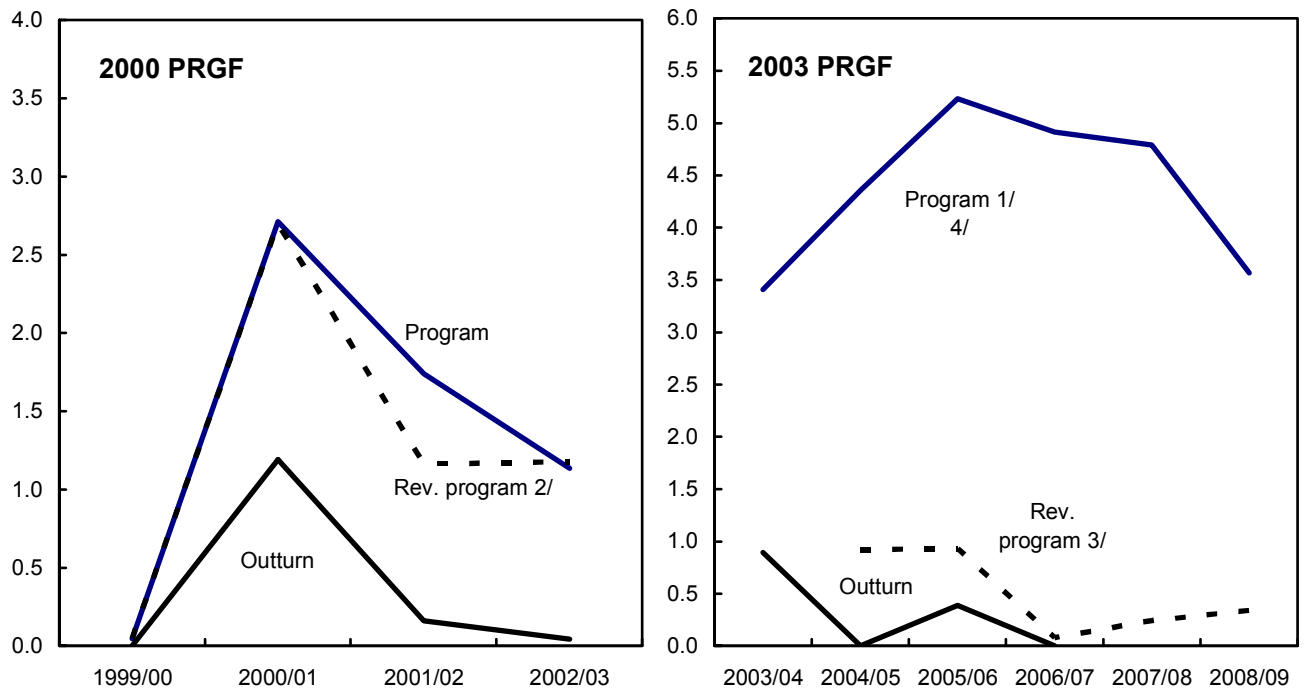

Sources: IMF country documents.

1/ Total unidentified gross external support excluding project support.

2/ Revision to 2000/01 reflected augmented program, after increase of access and effects of drought.

Revision to 2001/02 reflected revised program, assuming that pledged aid will be disbursed.

Revision to 2002/03 reflected financing gap under IMF projections, to be covered with aid.

3/ Revision to 2004/05 and 2005/06 reflected revised program as approved by Board during First PRGF review. Revision to 2006/07 reflected revised program as approved by Board during Second PRGF review. Revision to 2007/08 reflected revised program as approved by Board during Third PRGF review.

4/ 2003/04 reflects financing gap under IMF projections, to be covered by Paris Club debt rescheduling. 
the Board called for stronger actions than those suggested by staff to bring the program ontrack. ${ }^{30}$ In mid-2001, the Board indicated that staff should not travel to Nairobi until governance conditions had been met. The local diplomatic community was also active. In late-1998, a Nairobi diplomats' forum known as the "Economic Governance Group" (EGG) expressed doubts to mission teams with the authorities' commitment to reforms and the follow-up to Goldenberg. The EGG proposed a timeline for Fund staff visits and Board meetings and suggested specific prior actions for ESAF discussions. The EGG urged that donors be included directly in program negotiations and in assessing whether prior actions were met. While management and staff reaffirmed that program conditionality must be set exclusively by the Fund, donors' views nevertheless weighed heavily, given the risks of possible financing gaps. Moreover, staff briefings for selected Directors prior to ICM sessions at the Board, often an important channel for consensus building, caused tensions with other Directors (and the authorities), who felt that decisions had been taken in advance. Donor pressures reemerged in 2005-06, in the wake of Anglo-Leasing, although donor assistance was less important than in the 1990s.

\section{Debt relief was limited to nonconcessional rescheduling of arrears to Paris Club creditors in 1994, 2000, and 2004, largely on export credits from the 1980s. ${ }^{31}$ In 1993,} staff advised the authorities to seek nonconcessional terms for rescheduling of arrears only, in order to help maintain credibility with private creditors and access to export credits. Major Paris Club creditors also considered that there was no reason to grant concessional rescheduling terms, even though Kenya was eligible. Kenya was eligible for concessional treatment (Naples terms) in 2000 and 2004, but the authorities elected for nonconcessional rescheduling to limit strains with private creditors (comparability of treatment). The nonconcessional nature and limited coverage of the reschedulings did not attract more financing for Kenya, and more concessional terms may have helped free resources for investment or poverty-reducing spending, or contributed to a lower domestic debt burden. ${ }^{32}$

\section{In spite of the difficult track record, market observers favorably noted Kenya's} low dependence on donors. Two rating agencies recently cited relatively limited donor dependency as a positive factor, as it served to strengthen fiscal discipline and allowed Kenya to better develop its revenue administration, domestic debt market, and financial system. Low donor dependence also led to greater ownership of PFM reforms.

\footnotetext{
${ }^{30}$ Directors called for "determined efforts in fighting corruption more broadly and beyond the areas of agreed actions." At an informal session in May 1999, Directors viewed implementation of prior actions on governance as "formalistic," and recommended postponement of negotiations on a new program.

${ }^{31}$ The leaked Kroll report alleged that cost overruns on a large hydroelectric project in the $1980 \mathrm{~s}$ - and corresponding elevated external borrowing - were due to high-level kickbacks from contractors.

${ }^{32}$ The nonconcessional reschedulings seem at odds with a zero ceiling on nonconcessional debt through much of the period.
} 


\section{Lessons Learned And Policy Challenges Going Forward}

\section{A. Summary Assessment and Lessons Learned}

\section{A striking feature of the 1996, 2000, and 2003 arrangements is that they went} off-track quickly, and remained off-track for long periods. The 1996 and 2000 arrangements also came at the time of droughts. All three were three-year arrangements with significant access - 55 percent of quota. The 2000 and 2003 arrangements were augmented.

\section{The engagement was dominated by governance concerns and became too reactive:}

- The poor anti-corruption track record during the 1990s created its own dynamic, providing a rationale to add measures at the margin, when a strategic regrouping was warranted. As specific guidance on governance came only in 1997, four years after Goldenberg, the Kenya case involved an element of "learning by doing."

- $\quad$ Extensive prior actions used to test ownership taxed capacity, invited donor pressures, and inhibited transparency and signaling clarity. When measures were extended or modified due to incomplete action or changing events on the ground, the Fund was seen as "shifting the goalposts." The authorities also became concerned with micromanagement and "mission creep" through the extension of conditionality outside the Fund's area of expertise. While this dynamic was driven to a large extent by weak ownership and continuing revelations of corruption, the approach became too diffuse and reactive in 1995-99, was overambitious in 2000-01, and was overly influenced by donor pressure.

- $\quad$ There was a refocusing with the 2003 Article IV consultations and PRGF, but the approach again became reactive in 2005-06. The Bank's anti-corruption initiative and engagement both prolonged and assisted another regrouping. The conclusion of reviews in 2007 was a departure from the pattern, and was supported by improved macroeconomic performance and a better track record on structural and governance reforms.

- $\quad$ The EPA team recognizes that the confluence of weak ownership, a mixed track record, and a string of corruption cases made engagement with the Moi administration complex. With the exception of the period immediately after the 1993 crisis and the short Dream-Team era, there were few instances or champions of reform. With various reasons to remain engaged, the Fund did so, and provided important policy guidance and TA, in spite of a succession of off-track programs. The results of the engagement in some cases came later than expected or programmed (e.g., parastatal reforms). The more positive results from 2003 onwards reflect, in part, a change in this dynamic. 


\section{Kenya's experience highlights several lessons:}

- $\quad$ The Fund's concerns with governance were warranted, but the approach became bogged down. Goldenberg was shocking and seen as symptomatic of a culture of corruption and impunity. For fiduciary reasons alone, the Fund was right to insist on a thorough accounting of the scandal and assurances that channels for theft of funds were closed. When follow-up was uneven and incomplete, confidence and relations suffered. Over time, however, measures became overly reactive, and a strategic regrouping or disengagement was needed. The core focus on finding mechanisms to strengthen prosecutorial authority in 1995-99 and 2005-06 put the Fund in the politically sensitive position of enforcing accountability. It set programs up to fail.

- Governance measures should be of critical importance for achieving the objectives of Fund arrangements and be well articulated as such. They should aim to increase transparency, control, and accountability in areas where the Fund has expertise (e.g., PFM, financial oversight and regulation). The Bank should take the lead role in areas where it has greater resources and expertise, as it did eventually with the GAP. A further lesson is that the reaction by the authorities to specific scandals should be to get the details straight through an external audit, to get information out quickly and in full through publication of audit reports, to promptly close channels for misuse of funds and suspend culpable officials, and to seek the recovery of funds. With these measures in place, prosecution should be left by the Fund to the domestic legal system and other stakeholders.

- $\quad$ Opportunities for change come infrequently and should be seized by both sides through focused actions that avoid straining capacity. When the Fund attempted to refocus the governance approach in 2000 , it did so by expanding the scope of the anticorruption agenda. An opportunity to build a track record and confidence with the hand-picked Dream Team was lost. By contrast, the Kibaki administration was given initial support and the benefit of doubt with the completion of the first PRGF review. The resumption of the PRGF in 2007—on the basis of the GAP and good performance, World Bank engagement on governance issues, and a change in the Fund's approach to governance in Kenya - was a similar departure from the past pattern. On the authorities' side, greater commitment was needed throughout the period, particularly given perceptions of the "donors' dance."

- Consideration should be given to changing program modalities when there are serious governance concerns and a poor track record. In spite of disappointing performance, wide-ranging, multiyear, high-access arrangements were agreed in 2000 and 2003, when the Fund tried to take advantage of "windows of opportunity." To some extent, this was dictated by the instruments available. A short-duration, low-or-no access, LIC-targeted instrument was not in place until the PSI in late-2005, and then it was aimed at "mature stabilizers." A program architecture along the lines of the PSI, in 
which missing two scheduled reviews causes a program to be terminated, might have allowed for regrouping and clearer signaling. ${ }^{33}$

- $\quad$ Transparency and clarity suffer when programs languish off-track. Heavy reliance on prior actions and frequent Informal Country Matters (ICM) - less visible by their nature - combined with the authorities' infrequent consent to publication of staff reports to severely constrain public communications on Kenya. ${ }^{34}$ Parliamentarians and opposition politicians at times complained to staff that they were unaware of the content of prior actions and even Fund arrangements. The Fund will need a more effective communications strategy going forward and will also need to secure space to present an independent view, in case perceptions differ from those of other parties.

- A final lesson is that Kenya was able to cope relatively well without extensive external support (aside from successive Paris Club reschedulings). Beginning with their response to the 1993 crisis, the authorities managed policies relatively cautiously, helped by Fund policy advice. Dedicated technocrats pushed reforms throughout the period, and progress was made particularly in administrative areas (e.g., revenue administration, parastatal reforms, and business licensing reform). However, infrastructure and poverty-reducing spending was constrained during the period.

\section{B. Policy Challenges Going Forward}

\section{Notwithstanding the disappointing past engagement, the Fund can play an important role in helping the authorities design and implement their policy agenda going forward. The postelection violence made clear the need for sustained and equitable growth and for further institutional gains. These recent developments and Kenya's long and contentious relations with the Fund might be seen as grounds for a cautious approach or a "cooling off." However, the track record of improved performance over the past few years is encouraging, and the Fund can help foster sound macroeconomic policies and greater transparency, complementing the efforts of other partners and helping Kenya reach its full growth potential.}

\footnotetext{
${ }^{33}$ The Kenya case raises an important issue of access and PRGF program design, as the authorities could have insisted on requesting full access remaining under the 2003 arrangement when reviews were completed under the extension. This points to a broader issue of whether PRGF architecture should allow for a more explicit reconsideration of access to take account of extensive program slippages and changes in the balance of payments position.

${ }^{34}$ The Kenyan authorities have not agreed to publication of recent reports and letters of intent, and only the 2001 and 2003 Article IV reports and the 2003 PRGF request are available on the Fund's website. The PINs for the 2004 and 2006 Article IV consultations were not published.
} 
67. With a political accord now in place, the authorities need to quickly rebuild confidence and sustain the recent pick-up of growth, even as global conditions become less favorable. This will require further progress in three broad areas: continued macroeconomic stabilization, sustaining private sector-led growth, and enhanced attention to pro-poor policies.

\section{Continued macroeconomic stabilization}

- $\quad$ The authorities need to further refine the CBK's instruments to analyze and address monetary and financial market developments and to be prepared to allow greater interest and exchange rate flexibility in pursuit of price stability. Banking supervision is still clouded by legal gaps, and the statistical base needs further improvement. ${ }^{35}$

- In the fiscal area, increases in capital and social expenditures (and improvements in spending efficiency) should be considered, in line with a further pick-up in revenue performance, efficiency gains in other spending areas, a cautious increase in external borrowing, and additional donor support. The authorities should continue to be cautious in including donor assistance in their medium-term framework and annual budgets. Sustained PFM improvements are needed to ensure efficient spending and operations, to help identify areas for savings, and to give greater confidence to the public and donors. A debt strategy is needed to take into account domestic market capacity and development and Kenya's financing requirements and vulnerabilities. Further TA would be helpful, including next-generation revenue reforms.

- $\quad$ Continued PFM reforms should also remain at the core of the Fund's governance approach. Engagement by the Bank and other donors in governance areas outside the Fund's core expertise will be important. This would be facilitated by timely and comprehensive follow-up by the authorities to the 2006-07 GAP.

\section{Sustaining private sector-led growth}

- Business climate reforms were important to the recent pick-up of growth, and further efforts would help restore confidence and boost investment. A structured program to address infrastructure deficiencies is needed, but one that does not substantially increase risk or worsen debt sustainability. Improvements in investment planning, prioritization, and assessment are needed. The government should move cautiously on nonconcessional borrowing, including by parastatals, and with public private partnerships.

\footnotetext{
${ }^{35}$ Despite relatively strong capacity and TA from the Fund, data weaknesses remain, including in balance of payment and price statistics.
} 
- The development of a sound financial sector strategy is overdue, including for the recapitalized NBK. Greater competition and efficiency are needed, including to ease pressures to regulate bank charges and address concerns with access to finance in rural areas and by SMEs. Reforms are needed to strengthen NSSF governance and ensure its long-term solvency. Further TA would be helpful in these areas.

- $\quad$ The recent strife underscored Kenya's importance in the regional economy. Increasing attention to regional integration and spillovers would be desirable and would keep a focus on the efficiency of Kenya's infrastructure and key remaining parastatals.

\section{Enhanced attention to pro-poor policies}

- $\quad$ The new government will need to give renewed focus to poverty and distributional aspects, including under a new PRSP. This should be complemented by better expenditure targeting and renewed reforms of civil service employment and wages.

\section{Risks}

68. There are a number of risks to continued engagement. The political situation is the most obvious risk, and a key challenge will be to build a policy consensus, ensure greater transparency and accountability, and distribute gains of growth more widely. Kenya's complex political economy suggests that solutions will not be found easily. This may mean that ownership and the pace of reforms will continue to be uneven.

69. Political pressures might undermine Kenya's past caution on macroeconomic management and external borrowing. New initiatives, such as constitutional and political reforms, decentralization, and infrastructure, need be carefully designed and managed. The Fund could provide advice on design and assess macroeconomic implications.

70. Continued risks on governance cannot be discounted. While progress was made in a range of institutional and legal areas, the new government should recognize Kenya's reputational risk in the governance area and take a proactive stance. If a new scandal emerges, the authorities should react promptly and decisively.

71. There are other, long-standing sources of risk. These include vulnerability to drought, commodity price fluctuations, and security threats.

\section{Framework for Future Fund Engagement with Kenya}

72. There are several options for continued cooperation. The choice should depend in the first instance on Kenya's needs for financing, policy advice, monitoring, and signaling. If there is strong ownership, logical options would include a PRGF or a PSI. 
73. A follow-up PRGF would provide continuity and a strong context for close Fund engagement. A PRGF with standard access for a sixth-time user ( 25 percent of quota $)$ - or additional access, if needed - would allow for support in the wake of the recent disruption and dislocation. ${ }^{36}$ The program should be streamlined and focused. A new PRSP would be needed.

74. A PSI would have a number of attractive features. Like a PRGF, a PSI would provide a platform for frequent policy advice, monitoring, and signaling (and require a new PRSP). However, a PSI may be of a duration of one to three years - more flexible than a PRGF (a minimum of three years). A shorter PSI might allow for a focused track record in a few key areas (e.g., PFM and public enterprise reforms, financial sector strategy). A PSI might also serve as a disciplining device and provide greater signaling clarity, as a PSI arrangement is terminated upon noncompletion of two consecutive scheduled reviews. This carries risks, given the past record of delays, but these could be mitigated by focused conditionality and realistic timetables for implementation. An important consideration will be the authorities' own interest (or non-interest) in a particular type of arrangement, and Kenya would need to meet the PSI test as a mature stabilizer.

\section{Consideration could also be given to maintaining a surveillance-only relationship.}

This would signal graduation from reliance on a program relationship, while retaining a scheduled policy dialogue. The modalities of surveillance could be tailored to provide for enhanced monitoring, perhaps tied to the budget cycle and the monetary program, given past difficulties in meeting targets. A key drawback is that it represents a less intense and frequent policy dialogue, and thus a weaker signal. There are also risks that Fund staffing and TA resources could be cut, leading to less engagement at a key time. The EPA team views that a surveillance relationship should be a mutual goal, but somewhat later. Under all of these options, the authorities are strongly encouraged to agree to publication of Fund staff reports.

\section{No formal "exit strategy" seems needed at this stage, particularly if Kenya moves} to a PSI arrangement. The Fund should be flexible in the duration of its continued engagement with Kenya, and we see a case for some form of enhanced involvement—-beyond the normal Article IV consultations - through the next election cycle.

\footnotetext{
${ }^{36}$ This counts the 1989 ESAF and subsequent ESAF and PRGF arrangements in 1993, 1996, 2000 , and 2003.
} 


\title{
APPENDIX I. KENYA's POLITICAL ECONOMY
}

\begin{abstract}
Developments since the December 2007 elections have drawn attention to Kenya's complex political economy and ethnic make-up. Five groups each make up at least 10 percent of the population, with Kikuyus constituting the largest share at just over 20 percent. Asian and Muslim communities are prominent in Kenya's cities and along the coast. Reflecting the ethnic composition and regional dispersion, the constitution requires that a presidential candidate secure at least twenty-five percent of the votes cast in at least five of eight provinces.
\end{abstract}

Regional and ethnic issues have long colored Kenya's political landscape. For nearly four decades, the country was governed by the KANU, and a one-party system was enshrined in the constitution in 1982. Maintaining peaceful tribal relations was often cited as the rationale for the single-party approach. The system also provided for considerable patronage and corruption opportunities, with some observers suggesting that specific ministries and parastatals were "reserved" for different ethnic groups. At the same time, the principal actors in major corruption scandals were not from a single ethnic group.

\section{Donors regarded Kenya's single-party politics as increasingly authoritarian through the 1980s, following a coup attempt against President Daniel arap Moi in 1982. Raila} Odinga, the opposition candidate in the disputed 2007 elections, was implicated in the coup and held without trial for six years. A "queuing system" that was used in the 1988 general elections, in which voters were forced to line up publicly for candidates, rather than voting by secret ballot, also colored donor perceptions. The murder of foreign minister Robert Ouko in 1990 added to concerns. Some observers have suggested that the end of the Cold War also changed donors' views of Kenya, and new commitments of aid to the government were suspended from late 1991.

Kenya's single-party system was rescinded in 1991. Since then, the political landscape has been characterized by frequent splintering and regrouping of parties and election-related violence in 1992 and 1997, although not on the scale of the recent turmoil. Elections have also brought fiscal and financial pressures and have coincided with major corruption scandals (Goldenberg in 1992 and Anglo-Leasing in 2002) and the build-up of fraudulent domestic arrears. President Moi, from the smaller Kalenjin tribe, displayed considerable skill in manipulating ethnic politics and keeping his opponents off balance with surprise political moves and ministerial shifts. For example, Raila Odinga's party was brought into the government in 1997 and again in 2001 and even merged with KANU. President Moi's designation of a successor in the run-up to the 2002 elections was similarly surprising, as he passed over several well-known politicians for Uhuru Kenyatta, the son of the first Kenyan president, Jomo Kenyatta, and a relative newcomer to the political scene at that time. These maneuvers have also wrong-footed the donor and foreign investor communities. 


\begin{abstract}
A key theme of the 2002 elections was to move beyond the complex, quarter-century tenure of President Moi to introduce economic and political reforms, including creation of a prime ministerial post and presidential age limits. Other reforms would have addressed land issues and regional and ethnic concerns through decentralization (e.g., greater authority for Muslim courts). However, a constitutional referendum was rejected by voters in November 2005, leading to the dissolution of the cabinet of President Kibaki and a split in the Kibaki-Odinga coalition that won the 2002 elections. This, in turn, set the stage for the 2007 election contest. The events of the past five years underscore a key legacy of the Moi era, KANU's long rule, the patronage system, and the constant maneuvering of political figures and parties: political fragility.

In spite of this complex context, Kenya has long been seen as a haven of stability in a difficult region, particularly given conflict in neighboring Somalia, Sudan, and Ethiopia. In addition to a multi-party political system, Kenya has an active news media and civil society. This perception of stability has persisted, even though Kenya suffered from high-profile terrorist attacks in recent years, including on the U.S. Embassy in Nairobi in 1998 and on coastal resorts in 2002. Although a political stand-off and violence followed the disputed 2007 elections, a political resolution reached in February on a power-sharing arrangement between Mr. Kibaki and Mr. Odinga may set an important example for furthering democracy in the region.
\end{abstract}




\section{APPENDIX II. KENYA’S RELATIONS WITH THE WORLD BANK}

\section{Kenya's collaboration with the Bank paralleled its fitful relations with the Fund:}

- $\quad$ During the 1990s, Bank budget support was constrained by the authorities' poor track record, particularly on public sector management and agriculture liberalization. Only the first tranche of a 1996 structural adjustment credit was disbursed, just after approval of the ESAF. The second tranche and augmented financing were not released, and the loan was closed in June 1998.

- $\quad$ Budget support was renewed with a loan in August 2000 — coinciding with approval of the PRGF. A second tranche was disbursed in December 2003; however, the loan was closed in 2004, with a final, third tranche cancelled. The Bank later rated the outcome of the loan as unsatisfactory, although it noted that the Kibaki government had made a promising, albeit cautious start in reforms to improve Kenya's investment climate. $^{37}$

- $\quad$ The results of key project loans were also mixed. A 1996 urban transport infrastructure project was clouded by kickbacks, contract rigging, and theft of funds, including by Bank staff. A 2000 HIV/AIDS project became bogged down by political infighting and "grave fraud and mismanagement." However, a 1997 energy sector project contributed to an expansion of electricity generation capacity, greater transparency in pricing, and elimination of subsidies. The project also led to unbundling of the power sector and establishment of an independent regulatory board-prerequisites for subsequent investment and privatization. A 2000 public sector management TA project aimed to support civil service rationalization, legal and judiciary reforms, improved PFM practices, and coordination of reforms across the government. Following the 2002 elections, activities were extended to strengthening judiciary and court capacity. While the project helped set the basis for later gains in many areas, the project review concluded that it was critical to keep reforms simple and focused, with realistic expectations for implementation and an effective communications strategy.

\section{Bank project lending improved over the past five years, despite the temporary suspension of new lending in late 2005. The share of projects "at risk" declined} significantly, and audit compliance improved. The Bank's CAS was extended by one year in early 2007 to support project lending operations and implementation of the GAP. The

\footnotetext{
${ }^{37}$ The Bank project completion report (\#30969) suggested that the Bank had overestimated the willingness and ability of the Moi government to implement reforms and wrongly assumed that the small Dream Team could overcome internal opposition. Lessons learned included focusing on a limited set of reforms through annual, single-tranche credits, strengthening consultations with parliament, civil society, and other stakeholders, and developing an effective communications strategy.
} 
extension also aimed to address emerging concerns with uneven development and inequity through better geographic and demographic targeting of Bank projects. Budget support was not renewed. 


\section{APPEndix III. Public ENTERPRise Reforms in KENYA}

Successive Fund arrangements appropriately targeted public enterprise reforms, with gradual, but considerable success. In the early 1990s, governance problems and financial mismanagement were acute at several major public enterprises (PEs), the inefficient operations of which seriously constrained Kenya's economy (ports, transportation, telecommunications, agriculture storage and marketing, and energy). PEs had easy access to overdrafts with state-owned banks, so that mismanagement also had financial sector implications. A 1991 policy paper of the Kenyan government divided PEs into strategic and nonstrategic firms. The authorities did not favor sale of strategic PEs, but rather strengthening of oversight and operations. Throughout the period, the authorities were concerned to retain Kenyan ownership of PEs. This position began to shift in 1999, when they agreed to foreign participation in privatization.

\section{A first phase of PEs reforms (1993-99) aimed at limiting fiscal pressures from "strategic" firms and at sale of nonstrategic firms. This phase was broadly successful, although progress was slower than anticipated. Half of the 210 nonstrategic enterprises were sold during the $1994 \mathrm{ESAF}$, and divestiture continued thereafter. Explicit program measures also targeted cost-cutting and improved performance in four strategic PEs-KPTC, the NCPB, KPLC, and KR — with assistance from the World Bank. In parallel, a 20 percent stake in the NBK was floated in October 1994. Progress with improving financial performance of KPTC and NCPB proved difficult, however, reflecting continued mismanagement. The 1996 ESAF brought a new impetus, and by end-1997, management of a key container terminal operated by the Kenya Ports Authority had been contracted out, a restructuring plan for KR had been adopted, NCPB began operating on a commercial basis, Kenya Airways was privatized, a strategic restructuring and privatization plan for KPTC was approved, direct government ownership in NBK was reduced to 26 percent, and KPLC was separated into distribution and generation firms. By end-1999, KPTC had been separated into three entities, and a decision was made to privatize Kenya Telkom (later reversed - see below). Despite slower-than-expected progress, reform was moving in the right direction.}

A second phase from 2000 focused on restructuring or privatization of "strategic" PEs. Major success was registered, especially in 2006-07. Under the 2000 PRGF, reforms suffered setbacks, as a transaction for Telkom was cancelled after bids had gone out, and privatization of KCB stalled. The 2003 PRGF aimed to complete the agenda, while improving transparency. A Privatization Act was passed in 2005, and a privatization commission was established in 2007. Progress with transactions was achieved through initial public offerings (IPOs) in the energy, sugar, and insurance sectors - helping to ensure shareholding by the Kenyan public — and through sale to strategic investors (Telkom). The NBK was restructured in May 2007, and a privatization strategy was approved in November. A management contract and a concession agreement were put in place for KPLC and KR, 
respectively. Operations of the PEs sector improved through performance contracts piloted in 2004/05 and rolled out in 2005/06 and through recruitment of professional managers.

Goals under successive Fund arrangements were ambitious, and the experience showed that reforming large, complex parastatals can go forward, albeit gradually and with sufficient ownership. Weak economic conditions (and layoffs) may have undermined the environment for earlier reforms. The recent focus on strengthened operations and management - rather than on transactions - was well aligned with the authorities' own policy priorities. A key factor in success was close involvement of the World Bank in the reforms. 


\section{APPENDix IV. RATionalization OF Civil SERViCe EMPloyMent}

\section{During the 1980s, the civil service and number of ministries in Kenya grew}

substantially. The 1989 ESAF included benchmarks on wage bill growth, but performance was mixed. The authorities issued a draft civil service reform program in 1992 to cut positions by 25 percent over 5 years. Donors were asked to help finance separations, but with aid frozen in 1991 and upcoming elections, the program did not progress.

Reforms advanced with the 1993 SMP and one-year ESAF. The civil service reform program was approved in July 1993, aiming for a sharper reduction of positions - by nearly 40 percent by mid-1998. The cuts excluded teachers. Staff reductions progressed in line with targets under the SMP and the ESAF through end-1995. Progress was also achieved on an ambitious agenda for restructuring and rationalizing ministries, part of program conditionality.

While reforms also continued initially under the 1996 ESAF, they were derailed by wage hikes in the run-up to the 1997 elections. Reforms under the 1996 ESAF stressed the importance of improving the pay of high-level civil servants and introducing an automatic personnel database. Position reduction targets were revised and only slightly undershot in 1996; however, in the run-up to elections in 1997, an ambitious wage agreement with teachers (200 percent over five years and 35 percent in 1997/98) and civil servants (18 percent in 1997/98) was concluded. The big hike reflected, in part, the erosion of wages, which were reported to have declined by 25 percent since 1990, and by more than 50 percent since 1980. Only the first phase of the teachers' agreement was implemented, however, although it was revived in $2003 / 04$ by the new government.

Parts of the reform continued even though the 1996 ESAF arrangement went off-track. Ghost employees identified in censuses conducted before the establishment of the new payroll system were reduced, and ministerial rationalization continued. In September 1999, the number of ministries was reduced from 27 to 15 .

During the 2000 PRGF, further staffing cuts were achieved, but structural reforms of the wage bill did not advance. A functional review of ministries and departments was completed, and a new retrenchment program was designed. The program aimed for a further reduction of 48,000 employees. By September 2000, cuts of more than 25,000 were completed, but after that, the program stalled.

Over the past five years, a relative reduction in the wage bill took place, although mainly due to high GDP growth. Progress in civil service reform was mixed. Actions included reforming the minimum wage setting mechanism, harmonizing wages across the general government, and continuing a general hiring freeze, with flexible application for poverty-reducing priority sectors. However, a review and consolidation of allowances was not finalized, different pay review bodies were not harmonized, and ad hoc salary increases continued. 
Over the entire period, central government administrative staffing was cut, but this did not reduce the wage bill as a share of GDP. Increases in wages and noncivil service positions (e.g., teachers) limited savings. Problems with the pay structure and competitiveness were not fully addressed. Middle-level employees remained underpaid, relative to low-level staff. 


\section{Appendix V. The Ambitious Agenda of The Dream Team}

Staff began working with the Dream Team in July 1999. During a mission that monththe first of two to undertake the 1999 Article IV consultations - staff developed a list of 13 "priority measures" in five broad areas: (i) enhancing accountability; (ii) strengthening oversight bodies; (iii) strengthening budget planning and execution; (iv) changing incentive mechanisms faced by potential participants in corruption; and (v) removing rent seeking opportunities. Specific actions included:

- $\quad$ Measures to enhance transparency of procurement by tender boards and parastatals.

- $\quad$ More adequate staffing and support for KACA.

- $\quad$ Assignment of financial controllers from the Treasury to line ministries to countersign all expenditure commitments to ensure consistency with budgetary ceilings.

- $\quad$ Establishment of widely publicized rules to limit government payments for expenditure committed outside the existing financial regulations.

- $\quad$ Elimination of all external duty exemptions and waivers except those specified by international treaties.

During the second mission, in September, staff found that a number of the measures were underway or completed. However, during the Board discussion of the Article IV consultations in December, Directors stated that more would need to be done before a program could be put in place. A follow-up mission in January targeted 17 additional measures to be "implemented in the near future." These included:

- $\quad$ Adoption of international standards in tendering.

- Strengthening of reporting of transactions of line ministries by having them audited by the Office of the Internal Auditor

- $\quad$ Requiring that all public officials and members of government declare their assets upon appointment and every three years thereafter or upon leaving service, whichever comes first.

- Incorporating all extrabudgetary transactions into the budget.

- $\quad$ Issuing a statement to inform the public that Comptroller and Auditor General $(\mathrm{C} \& A G)$ reports are available for purchase from the government printing office. 
- $\quad$ Providing adequate budget support to the C\&AG, KACA, the Auditor General, and the KRA.

- $\quad$ Strengthening further the capacity of the Auditor General's office and merging it with the Office of the C\&AG.

- $\quad$ Authorizing the Treasury to refer cases of alleged misuse of public resources to the KACA within three months after deliberation of reports prepared by the parliament's Public Accounts and Public Investment Committees.

Finally, the brief for a subsequent mission in May 2000 stated that the authorities had committed to implement a significant number of governance measures "in the weeks ahead" from a Cabinet-approved list of 56 actions.

The 2000 PRGF was approved in August. 


\section{APPENDiX VI. The ON-AND-OFF NATURE OF DONOR SUPPORT IN KENYA}

1989-92 ESAF. Bilateral balance of payments assistance was suspended in late 1991, due to slow progress on economic reforms and in moving to a multiparty political system. Project assistance continued, broadly as before.

1993 SMP and one-year ESAF. With successful stabilization under the 1993 SMP and a positive track record under the one-year ESAF, donors made new commitments of \$800 million at CG meetings in November 1993 and December 1994.

1995. Donors became concerned with temporary reversals of earlier liberalization steps, as well as ethnic tensions and the authorities' refusal to register a prominent opposition group, Safina, headed by Dr. Richard Leakey. Pledges made during the 1994 CG meeting were not disbursed.

1996-99 ESAF. During a CG meeting in March 1996, bilateral donors expressed continued concerns with "democratization of the political process, the rule of law, and the administration of justice in Kenya." While willing to consider release of committed funds, many donors were reluctant to make new pledges. Reflecting this skepticism, the ESAF assumed program financing to be phased out to zero after 1998. After the Goldenberg trial was suspended by the High Court and the ESAF arrangement went off-track in mid-1997, virtually no program support was disbursed for the next three years. Project support also fell slightly.

2000-03 PRGF. The PRGF arrangement assumed a slow but nevertheless ambitious return of budgetary assistance, including from the World Bank. However, no CG meeting had taken place, and financing needs would mostly be met through domestic financing and enhanced revenues, as well as a Paris Club rescheduling, which was approved in November 2000. The PRGF arrangement quickly went off-track, and donor budgetary support returned to virtually zero. Project support fell further.

2003-07 PRGF. A CG meeting, the first since 1996, was held in November 2003 eliciting new pledges of $\$ 4.1$ billion over three years. A political impasse over constitutional reform and the Anglo-Leasing scandal negatively affected disbursements, although donors initially remained supportive and endorsed the authorities' Anti-corruption Action Plan for April 2005-June 2006 at a CG meeting in April 2005. This changed when the World Bank froze funding to the Kenyan government in November 2005, and after John Githongo's memorandum, accusing close allies of Mr. Kibaki of corruption, was leaked in January 2006. While a forward-looking governance strategy allowed the PRGF arrangement to resume, donor budgetary assistance remained very low. 


\section{AnNeX I. The Views OF THE KenYan Authorities AND OTHER STAKeHOLders}

A draft of the EPA report was presented and discussed in Nairobi during June 23-25 with the Head of the Public Service, the Minister of Finance, the Governor of the CBK, and the Director of the KACC. Other discussants included the permanent secretaries of the ministries of finance, justice, medical services, water and irrigation, higher education, science and technology, planning, public health, and agriculture, and of the Office of the Prime Minister. Discussions were also held with representatives of civil society organizations (CSOs), labor unions, and donor agencies and embassies.

\section{Views of the authorities}

\section{Ministries of Finance and Justice, CBK and KACC}

Representatives of the ministries of finance and justice, the $\mathrm{CBK}$, and the KACC found the draft report to be balanced, objective, and realistic. However, they also highlighted a number of concerns:

- $\quad$ The draft EPA report rightly highlighted Kenya's track record of relatively prudent economic management and efforts by technocrats to pursue reforms throughout the period. However, while structural reforms also progressed, these did not generate sufficient growth for most of the EPA period. A critical legacy is the large population of underemployed youth, which presents a complex socio-political challenge.

- $\quad$ Program conditionality, particularly in the governance area, did not reflect realistic timetables or the constraints of Kenya's legal system and socio-political environment. In particular, the focus on prosecution and parliamentary passage of legislation was misguided, as it did not take into account the uncertain timetable of legal and judicial processes that were beyond the government's control. Requiring parliamentary passage of legislation also undermined the government's standing with the legislature, and thereby, program ownership.

- $\quad$ Past conditionality was not always well understood by the authorities or Kenyan society. While the authorities agreed to such measures as lifting price controls on maize, reducing subsidies, or cutting staffing in the civil service or in parastatals, these actions were not well understood or explained and therefore proved difficult to implement.

- $\quad$ MOF officials noted the concurrence of past Fund arrangements with drought conditions in Kenya and Paris Club reschedulings. This was a sign that Kenya had been forced by difficult circumstances to agree to unrealistic programs. They saw this as a response to vulnerability and contrasted the 1996 and 2000 programs, which 
went off track quickly, with the completion of reviews after 2006, when Kenya's economic situation was more favorable.

- $\quad$ CBK officials disagreed with the EPA's conclusion that central bank independence is overly constrained. Among other factors, they noted the fixed term of the governor, who cannot be removed for political reasons or disagreements over economic policy. Operational independence was also illustrated by recent policy steps that were undertaken without consultation with the government. Even so, they suggested that the formulation of rules for the new monetary policy committee would provide another opportunity to strengthen $\mathrm{CBK}$ autonomy.

- $\quad$ MOF, CBK and KACC staff agreed that the Fund and other donors had legitimate cause to focus on governance and corruption, but suggested that the focus on legal and institutional arrangements should have come earlier. Some officials stated that "strengthening prosecution capacity" became a "code" for removing from office or prosecuting specific individuals, while the Fund and other donors focused excessively on a "body count" of prosecutions. They questioned the macro- and program criticality of some conditions, and noted that Kenya did not benefit from significant increases in donor support even after completion of PRGF reviews in 2007.

- $\quad$ MOF staff also questioned whether Kenya received consistent treatment from the Fund compared with other member countries. They noted that the number of program conditions was typically larger than in other Fund programs and suggested that the Fund compare governance conditionality in Kenya with that in other countries.

- $\quad$ MOF staff also highlighted periods of what they perceived to be unfair "crossconditionality" among the Fund, the Bank, and other donors, particularly with the Bank on governance issues during 2005-06. They welcomed reference in the EPA report to Kenya's lack of donor dependency, including strong revenue performance.

- $\quad$ The authorities considered that the Fund too often reacted in the past to media reports, such as the Githongo resignation and the leaked memorandum from Mr. Githongo to President Kibaki. These reactions abstracted from core policies and contributed to a sense of "shifting the goal posts."

- $\quad$ Finally, MOF and CBK officials welcomed the EPA's recommendations to put in place a more robust public communications strategy, although they remain concerned that key issues would be politicized. This has contributed in the past to a "strictly confidential" approach, which has extended to publication of Fund staff reports.

Looking forward, MOF and CBK officials noted the importance of future Fund engagement for signaling to donors and financial markets, as well as serving as a platform for Fund policy 
advice and TA. They also noted that both sides needed to learn lessons from the past and to aim for a "partnership" rather than a "supervisory" relationship going forward.

\section{Other ministries and agencies}

Discussions on the draft EPA report were also held with the Head of the Public Service and the Chief Government Spokesman in the Office of the President and with the permanent secretaries of several line ministries and agencies, including the ministries of medical services, water and irrigation, higher education, science and technology, planning, public health, and agriculture, and the Office of the Prime Minister. These officials had a number of criticisms of the Fund's role and policy advice over the EPA period, including:

- $\quad$ A lack of flexibility in fiscal and monetary programs to accommodate social and investment spending, including wage bill ceilings.

- The impact of spending constraints on public services, including energy investment, agricultural extension, livestock vaccination, higher education, and public health. These policies, as well as the introduction of fees for health and education services, had led to a deterioration of social indicators. Retrenchment in the civil service and public enterprises critically weakened institutional capacity.

- $\quad$ The focus on governance by the Fund and donors at the expense of other reforms. This "ganging up" had led to a "negative branding" of Kenya internationally. In the governance area, the Fund and donors were too often manipulated by politicians and political groups in Kenya's competitive political environment.

These officials acknowledged some successes in Fund engagement, including liberalization of the exchange regime and domestic and international trade and improved control of major public enterprises. They also stated, however, that Kenya's track record of low inflation came via excessively high interest rates and constrained social and investment spending, which contributed to stagnation, poverty, and inequality. They asserted that the CBK lowered reserve requirements in 2003 - against the advice of the Fund - and that this eased banking sector liquidity and contributed to a pickup of credit and growth. The new government also raised wages and reintroduced free primary education, contrary to Fund advice.

These officials argued that after 2003, "home-grown" policies — as reflected in the government's Economic Recovery Strategy — were essential to improved performance. This suggested a clear lesson: when policies are initiated by a government with a clear sense of direction, rather than being driven or dictated from outside, sustained gains can be achieved.

The officials welcomed the Fund's efforts to assess the past engagement with Kenya and to draw lessons for future relations, but they stated that an independent external assessment 
would have been preferable. They called for a stronger partnership going forward - moving away from the Fund's role in the past as "external auditor and critic."

\section{Views of other stakeholders}

Representatives of labor unions, CSOs, donor agencies, and embassies also found the assessment to be balanced, objective, and realistic. ${ }^{38}$ They highlighted a key lesson of the importance of institution building in advance of far-reaching structural reforms. The need to further strengthen Kenya's institutions was made clear by the recent post-election violence, which some donor and CSO representatives attributed to a "winner takes all" political culture. Trade union officials also spoke of the need for greater independence among the legislative, executive, and judiciary branches, while CSO representatives lamented the poor state of Kenya's judiciary and urged the Fund to work cooperatively with other development partners to spotlight the need for improvements - for example, through the cost to business of lengthy court proceedings - and to promote change.

All of these groups agreed that the Fund was warranted to focus on governance during the EPA period, although they shared the EPA view that this focus had gone through several difficult phases. The recent focus on institutional arrangements was viewed as the right approach, although one that might not have worked earlier in the period. Donor officials called for further efforts to cement recent gains, for example, in the PFM area. Some suggested that further PFM improvements could lead to more financing being provided through the budget to "sector-wide programs," as in some neighboring countries. ${ }^{39}$

CSO officials welcomed the EPA's attention to consequences of Kenya's repayment of external debt and limited donor aid, including fewer resources for investment, slower growth, and higher poverty. Union officials strongly criticized the Fund's focus on retrenchment of civil servants and public sector employees. They argued that labor had borne the brunt of fiscal and structural adjustment in the 1990s, with negative effects for administrative capacity and social well-being, as laid-off employees did not receive adequate severance pay or other support. The Fund and Bank did not consult with unions at the time and did not work to put in place an adequate safety net for retrenched staff. Another area of criticism was trade liberalization, which union officials suggested decimated Kenya's automobile assembly and textile industries.

\footnotetext{
${ }^{38}$ Discussions with other stakeholders were carried out on the basis of a summary presentation.

${ }^{39}$ Donor representatives also cited the need for institutional improvements in areas other than economic management, including public access to information and the Internet, the media, education, and the judiciary, although they recognized that these were outside the mandate and core competency of the Fund.
} 
Representatives of CSOs argued for a more robust Fund public communications strategy and a wider dialogue with stakeholders, beyond the CBK and MOF. Trade union officials noted the importance of maintaining a resident representative to carry out an extensive dialogue with a range of stakeholders. However, CSO officials suggested that the Fund and donors had too often been drawn into Kenya's intense and complex political environment, having been seen as "taking sides" and supporting one political figure or another.

Representatives of CSOs and the donor community see a strong case for continued close Fund engagement. They noted that Kenya's development needs remain large and underscored risks and uncertainties, including the national unity government, which brings together three parties after contested elections. Risks and uncertainties also include constitutional change and possible devolution of authority to local governments, where there is weak capacity and a perception of poor governance. Donors see merit in another Fund arrangement, building on the improved track record of recent years and possibly facilitating increased budgetary support.

$\mathrm{CSO}$ and donor representatives also urged that governance remain a key focus of the Fund's engagement with Kenya. CSO officials observed that emerging creditors to sub-Saharan Africa have not focused on governance improvements in their activities. By contrast, regional and African peer review mechanisms have proved helpful. Some donors stressed that there needed to be a clear "division of labor" among agencies and embassies on governance, with the Fund remaining focused on governance issues within its core competency. 